\title{
Annals of Operations Research \\ A Multi-Objective Particle Swarm Optimization Algorithm for Business Sustainability Analysis of Small and Medium sized Enterprises

\author{
--Manuscript Draft--
}

\begin{tabular}{|c|c|c|}
\hline Manuscript Number: & \multicolumn{2}{|l|}{ ANOR-D-18-00112R1 } \\
\hline Full Title: & \multicolumn{2}{|c|}{$\begin{array}{l}\text { A Multi-Objective Particle Swarm Optimization Algorithm for Business Sustainability } \\
\text { Analysis of Small and Medium sized Enterprises }\end{array}$} \\
\hline Article Type: & \multicolumn{2}{|c|}{ S.I. : MCDM 2017} \\
\hline Keywords: & \multicolumn{2}{|c|}{$\begin{array}{l}\text { Neural Network, Particle Swarm Optimization, Multi-objective Programming, } \\
\text { Sustainability practices and performance }\end{array}$} \\
\hline Corresponding Author: & \multicolumn{2}{|c|}{$\begin{array}{l}\text { Fouad Ben Abdelaziz } \\
\text { Neoma business school, Rouen Campus, } 1 \text { Rue Marechal Juin,France } \\
\text { MONT SAINT AIGNAN, FRANCE }\end{array}$} \\
\hline \multicolumn{3}{|l|}{$\begin{array}{l}\text { Corresponding Author Secondary } \\
\text { Information: }\end{array}$} \\
\hline Corresponding Author's Institution: & \multicolumn{2}{|c|}{ Neoma business school, Rouen Campus,1 Rue Marechal Juin,France } \\
\hline \multicolumn{3}{|l|}{$\begin{array}{l}\text { Corresponding Author's Secondary } \\
\text { Institution: }\end{array}$} \\
\hline First Author: & \multicolumn{2}{|l|}{ Fouad Ben Abdelaziz } \\
\hline \multicolumn{3}{|l|}{ First Author Secondary Information: } \\
\hline \multirow[t]{3}{*}{ Order of Authors: } & \multicolumn{2}{|l|}{ Fouad Ben Abdelaziz } \\
\hline & \multicolumn{2}{|l|}{ Houda Alaya } \\
\hline & \multicolumn{2}{|l|}{ Prasanta Dey } \\
\hline \multicolumn{3}{|c|}{ Order of Authors Secondary Information: } \\
\hline Funding Information: & $\begin{array}{l}\text { Neoma Business School, France } \\
\text { (Seed Project) }\end{array}$ & Professor Fouad Ben Abdelaziz \\
\hline Abstract: & \multicolumn{2}{|c|}{$\begin{array}{l}\text { Sustainability is the major issue of small and medium sized enterprises (SMEs) all } \\
\text { across the globe. Although SMEs contribute to GDP of any country their negative } \\
\text { contribution to environment is also significant. Prior studies on SMEs' sustainability } \\
\text { mainly classified into three categories - the correlation between environmental and } \\
\text { social practices with economic performance, sustainable supply chain performance } \\
\text { measurement, and empirical research on sustainability practices. There is no study } \\
\text { that objectively derives the sustainable structure of SMEs through optimal combination } \\
\text { of sustainability practices (inputs) and performance (outputs). Therefore, the main } \\
\text { objective of this paper is to generate optimal structure of sustainable SMEs by } \\
\text { combining neural network and particle swarm algorithm while considering Multi- } \\
\text { Objective framework. The study uses data from } 54 \text { SMEs of Normandy in France and } \\
30 \text { SMEs of Midlands in the UK. The data was gathered through questionnaire survey. } \\
\text { As we do not have the explicit expression of our objective functions, we train a Neural } \\
\text { Network (NN) on our databases in order to enable the generation of value of the } \\
\text { different objectives for any profile. We design and run a multi-objective version of } \\
\text { Particle Swarm Optimization (MPSO) to generate efficient companies' structures. The } \\
\text { weighted sum method is then used for different weights. The comparison of observed } \\
\text { data and the results of the PSO analysis facilitates to derive improvement measures for } \\
\text { each individual SME. }\end{array}$} \\
\hline
\end{tabular}


Answers to reviewers comments.

Dear-Guest- Editor

We would like to thank you and thank the reviewers for their effort in commenting our paper. We have tried, in the revised version, to answer to all their concerns. We hope that the paper will fulfill your requirements.

All the best

The Authors

n.b. we have answered in Blue Below

COMMENTS FOR THE AUTHOR:

$* * * * * * * *$

Reviewer \#1: Minor Revision

Few concerns about the paper:

I would like the authors to stress on the limitations of their approach and to propose ways to overcome these limitations. They can also provide the perspectives and potential applications. This may present this in a section preceding the conclusion.

Please look at the new section preceding the conclusion. We have also modified the conclusion consequently.

There are few repetitions in the text that should avoided. Look at the introduction for example. Some formatting of the figures and tables is required.

We have double checked the paper and eliminated the repetitions from the text and arranged the formatting.

Reviewer \#2: The manuscript is clearly presented, well structured, well written, and easy to understand.

I would recommend to the authors to present ways to generalize such approach to qualitative researches and to stress on the limitations of such approach vis a vis other methodologies such as regression analysis for example.

Please look at the new section preceding the conclusion. We have addressed in the new section the reviewer's concern about limitations and generalizations. We have also addressed this in the new conclusion.

Reviewer \#3: Definitely, the manuscript can be accepted for publication after providing a language revision and improving the discussion and conclusion (Section 6). 


\title{
A Multi-Objective Particle Swarm Optimization Algorithm for Business Sustainability Analysis of Small and Medium sized Enterprises
}

\author{
Fouad Ben Abdelaziz ${ }^{1}$, Houda Alaya ${ }^{2}$, Prasanta Kumar Dey ${ }^{3}$ \\ ${ }^{1}$ NEOMA Business School, Rouen Campus \\ Boulevard André Siegfried - 76130 Mont-Saint-Aignan, France \\ Fouad.BEN.ABDELAZIZ@ neoma-bs.fr \\ ${ }^{2}$ Logistics and innovation technology research center, IHE Paris \\ And Tunis Business School, Tunisia \\ houdaalaya@yahoo.fr \\ ${ }^{3}$ Aston Business School, Aston University \\ Birminghan, UK \\ p.k.dey@aston.ac.uk
}

\begin{abstract}
Sustainability is the major issue of small and medium sized enterprises (SMEs) all across the globe. Although SMEs contribute to GDP of any country their negative contribution to environment is also significant. Prior studies on SMEs' sustainability mainly classified into three categories - the correlation between environmental and social practices with economic performance, sustainable supply chain performance measurement, and empirical research on sustainability practices. There is no study that objectively derives the sustainable structure of SMEs through optimal combination of sustainability practices (inputs) and performance (outputs). Therefore, the main objective of this paper is to generate optimal structure of sustainable SMEs by combining neural network and particle swarm algorithm while considering Multi-Objective framework. The study uses data from 54 SMEs of Normandy in France and 30 SMEs of Midlands in the UK. The data was gathered through questionnaire survey. As we do not have the explicit expression of our objective functions, we train a Neural Network (NN) on our databases in order to enable the generation of value of the different objectives for any profile. We design and run a multi-objective version of Particle Swarm Optimization (MPSO) to generate efficient companies' structures. The weighted sum method is then used for different weights. The comparison of observed data and the results of the PSO analysis facilitates to derive improvement measures for each individual SME.
\end{abstract}

Keywords: Neural Network, Particle Swarm Optimization, Multi-objective Programming, Sustainability practices and performance 


\section{Introduction}

The literature of business disciplines increasing refers the term sustainability as an integration of social, environmental, and economic responsibilities (Seuring et al., 2008). About 68 percent of the Global 250 firms generated a separate annual sustainability report in 2004 which considered environmental, social, and economic issues, in contrast to the primary emphasis on environmental reporting in 1999; in addition, 80 percent of these reports discuss supply chain-related issues (KPMG, 2005). Although sustainability of large organizations as focal company has been considered extensively in prior research along with their supply chain, researches on small and medium sized enterprises' (SMEs) sustainability issues and challenges are relatively less.

SMEs are the main part of any economy. $90 \%$ of world businesses happen through SMEs, $50-60 \%$ of world population work in SMEs. However, economic sustainability of SMEs are uncertain due to intense competitions along with several other issues. SMEs are socially and environmentally vulnerable as quite often they require to priorities economic sustainability over environmental and social. Prior research on SMEs' sustainability emphasizes on the role of corporate social responsibility and environmental management system on SMEs' business performance. Kerr (2006) explores SMEs strategies and policies to manage environmental issues and pressures. Walker and Preuss (2008) demonstrate how public sector could promote sustainability through sourcing from SMEs. Jenkins (2009) presents a corporate social opportunity model, which is innovation led, for new market, and with a business model. Another paper (Moore and Manring, 2009) discusses several different incentives (e.g. attractive to local and global clients, developing network of sustainable SMEs) to optimize sustainability. More recently, Hoof and Theill (2014) reveal that collaboration capacity is essential for effective implementation of cleaner production, which provide competitive advantages for sustainable supply chain management. In his paper, Johnson (2015) analyses why particular SMEs are more likely to adopt sustainability management tools. Bourlakis et al. (2014) study the relationship between firm size and sustainability performance and reveal that small firms are top performers and excel in most sustainable performance measures. Huang et al. (2015) empirically investigate the pressures and drivers that have been experienced by Chinese manufacturing small and medium enterprises (SMEs) in terms of green supply chain management (GSCM). Jayaram et al. (2014) study supply chain capability of family owned SMEs in India. The work by Govindan et al. (2014) focuses on identifying barriers to the implementation of a green supply chain management based on procurement effectiveness. Energy efficiency has been recognized as a primary means to increase the competitiveness SMEs (Trianni et al., 2016). In summary, prior researches have revealed correlations of social and environmental sustainability with economic performance and explored means for achieving sustainability of SMEs. Although they are important to transform SMEs for higher sustainability, the research on effect of combined operational, environmental and social practices of SMEs on economic and overall sustainability performance is scant. 
The main objective of this paper is to derive optimal structure of sustainable SMEs with the and output variables (business growth, turnover and environmental performance). We study the effect of main business variables including environmental and social management on business growth, turnover and environmental performance. We consider a multi-objective optimization model for our study and optimize the following objectives: the turnover, the environmental management and the business growth. The management decision variables are practices related to demand management, supply chain management, internal process management, environmental and social management.

The remainder of the paper is organized in the following five sections. Section 2 introduces theoretical foundation of the paper covering multi-objective Pareto solutions, neural network, and Particle Swarm Optimization (PSO). Section 3 describes the methodology for undertaking this research. Section 4, presents the algorithm that has been used for analyzing the data. Section 5 , demonstrates the results of the application of the proposed heuristic. Section 6 thoroughly discusses the results through explaining how these could facilitate both policy makers and individual SME owners to enhance sustainability performance.

\section{Theoretical concepts}

This section contains three parts. In the first part, we define the multi-objective programming formulation. We present the Pareto solutions and ways to generate them. In the second part, we provide the NN structure. In the last part, we explain our PSO heuristic.

\subsection{Multi-Objective Pareto Solutions}

Multi-objective Programming (MOP) has been intensively studied for more than four decades. It is used to deal with problems in which different objective functions are optimized simultaneously. In general, the MOP formulation is proposed in the following form:

$$
\begin{array}{ll}
\operatorname{Max} & F(x)=\left\{f_{1}(x), f_{2}(x), \ldots, f_{k}(x)\right\} \\
\text { s.t. } & x \in S
\end{array}
$$

where the index $k(k \geq 2)$ indicates the number of objective functions to optimize $f_{i}: \mathfrak{R}^{n} \rightarrow \mathfrak{R}$, $F(x)$ is the objective vector, the decision variable vector is $x=\left(x_{1}, x_{2}, \ldots, x_{n}\right)$ and $S$ represents the set of the feasible solutions.

Dominance is defined as follows: A decision vector $x^{\prime} \in S$ is dominated by another $x \in S$ if $f_{i}(x) \geq f_{i}\left(x^{\prime}\right)$ for all $i=1, \ldots, k$ and $f_{j}(x)>f_{j}\left(x^{\prime}\right)$ for at least one index $j$.

A decision vector $x^{\prime} \in S$ is called Pareto optimal (or efficient) if there does not exist another $x \in S$ such that $f_{i}(x) \geq f_{i}\left(x^{\prime}\right)$ for all $i=1, \ldots, k$ and $f_{j}(x)>f_{j}\left(x^{\prime}\right)$ for at least one index $j$. 
The solution for the MOP is the set of all non-dominated solutions called the Pareto (or efficient) set.

There are several approaches to solve a MOP such as the $\varepsilon$-constraint approach, the goal programming (GP) approach and the weighted sum approach.

The $\varepsilon$-constraint method (Haimes et al., 1971) consists in minimizing a primary objective function and transforming the remaining objective functions into inequality constraints as follows:

$$
\begin{array}{ll}
\text { Max } & f_{\ell}(x) \\
\text { s.t } & f_{j}(x) \geq \varepsilon_{j} \text { for all } j=1, \ldots, k, j \neq \ell \\
& x \in S
\end{array}
$$

where $\varepsilon_{j}$ is the maximum of $f_{j}(x), j \neq \ell, \ell \in\{1, . ., k\}$.

We can prove that any unique solution for an $\varepsilon$-constraint problem is an efficient solution.

The GP is proposed by Charnes et al. (1955). In the GP approach, the DM defines the goal of each objective. In general, the goal $\bar{z}_{i},(i=1, \ldots, k)$ is greater than maximum of $f_{i}(x),(i=1, \ldots, k)$. The aim is to minimize the deviations from goals. Therefore, the general GP model is as follows (Charnes and Cooper, 1963):

$$
\begin{aligned}
& \operatorname{Min} \sum_{\mathrm{i}=1}^{\mathrm{k}} \delta_{i}^{-}+\delta_{i}^{+} \\
& \text {s.t } f_{i}(x)-\delta_{i}^{-}+\delta_{i}^{+}=\bar{z}_{i} \text { for all } i=1, \ldots, k \\
& \quad \delta_{i}^{-}, \delta_{i}^{+} \geq 0 \text { for all } i=1, \ldots, k \\
& \quad x \in S
\end{aligned}
$$

where $\delta_{i}^{-}, \delta_{i}^{+}$are the negative and positive deviation variables from the ith goal. The obtained solution, if unique, is a Pareto optimal.

The weighted sum method was introduced by Gass and Saaty (1955), to transform a MOP problem into a uni-objective problem. Thus, a positive weight is assigned to each objective. Therefore, the objective is to maximize the weighted sum of all the MOP objective functions. The general weighted problem can be formulated as follows:

$$
\begin{aligned}
& \operatorname{Max} \sum_{\mathrm{i}=1}^{\mathrm{k}} \lambda_{\mathrm{1}} f_{i}(x) \\
& \text { s.t } x \in S
\end{aligned}
$$

where $\lambda_{i}>0$ for all $i=1, \ldots, k$ are the weight coefficient of objective function $f_{i}$, with $\sum_{i=1}^{k} \lambda_{i}=1$. An optimal solution of weighted sum method is also a Pareto optimal solution. 
In our study, and to determine a sample of efficient solutions, we use problem 4 for different weights and we consider our trained $\mathrm{NN}$ to generate the values of the two objective functions to be used by the MPSO algorithm.

\section{Neural networks (NN)}

The multilayer perceptron (MLP) method is the most studied NN. It has a feed forward structure due to the relation between inputs and outputs. Furthermore, the MLP technique starts by organizing the neurons, and then each layer considers the outputs of the previous layer as inputs. In general, the units are ordered in three types of layers, which are, input layers, hidden layers and output layers. (See Figure 1)

Figure 1. A two-layer artificial neural network with three inputs and two hidden units (Looney, 1997)

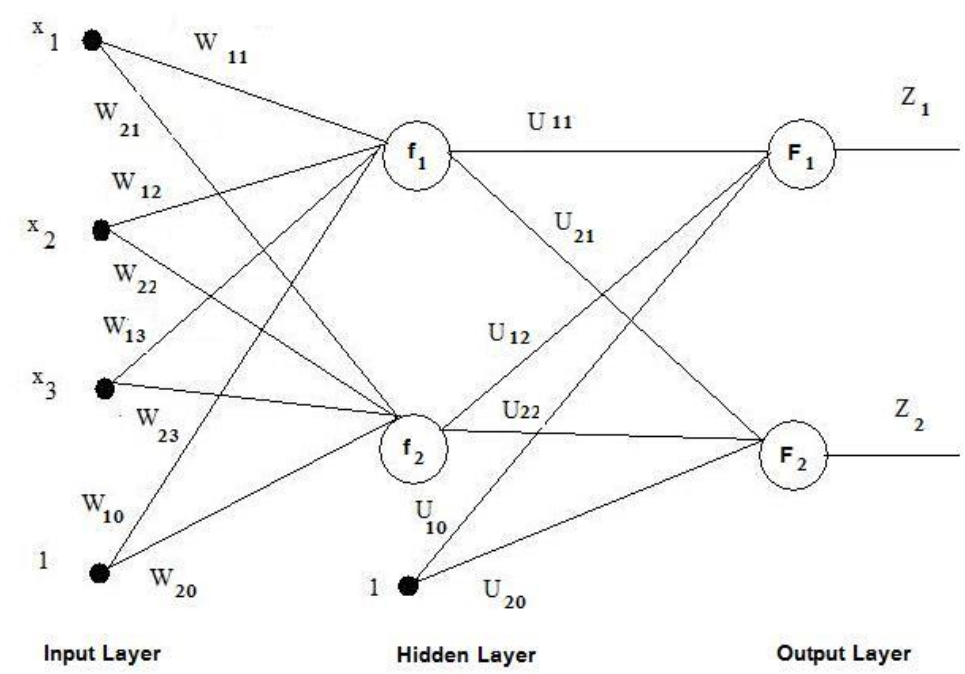

Figure 1 illustrates an example of MLP with three layers where $W_{i j}$ are the weights and $U_{j i}$ are the biases. The bias can be interpreted as a weight acting on an input clamped to 1 (Norgaard et al., 2000). $F_{j}$ are objective functions used respectively to calculate intermediary outputs and activated outputs $Z_{j}$. The MLP aims to find the best weights that join the inputs to outputs by using an activation function. Different activation functions are proposed in the literature such as sigmoid, hyperbolic tangent and threshold (Hu and Hwang, 2001). The most used activation function in the MLP is the sigmoid defined as follows:

$$
f(x)=\frac{1}{1+e^{-x / T}}
$$


where $T$ is a temperature parameter. The formulation defining the output in the function of the inputs is as follows:

$$
Z_{j}=g_{j}[x, \alpha]=F_{j}\left[\sum_{i=1}^{M} U_{j i} f_{i}\left(\sum_{l=1}^{N} W_{i l} x_{l}+W_{i 0}\right)+U_{j 0}\right]
$$

where $\alpha$ is the parameter vector containing the adjustable parameters of the network. To train the MLP, we need to adjust weights by employing the Back propagation technique (Looney, 1997). This technique contains three steps. The first step initializes the weight set with random variables. The second step updates the weight set with a strategy helping to have a less sum-squared error between generated and observed results. In the third step, if a stopping criteria is met, the process is stopped else new weights are generated with the second step.

\subsection{Particle Swarm Optimization (PSO)}

Eberhart and Kennedy (1995) introduce the PSO method. This heuristic simulates the flying of particles in a multiple dimensional search space (Ben abdelaziz and El-baz, 2010). Each particle possess four parameters: velocity $\left(V_{i}\right)$, position $\left(X_{i}\right)$, position of the best fitness encountered by the particle $\left(\right.$ pbest $\left._{i}\right)$ and best position of all particles ( gbest). (See Figure 2)

Figure 2. Particle Swarm Optimization

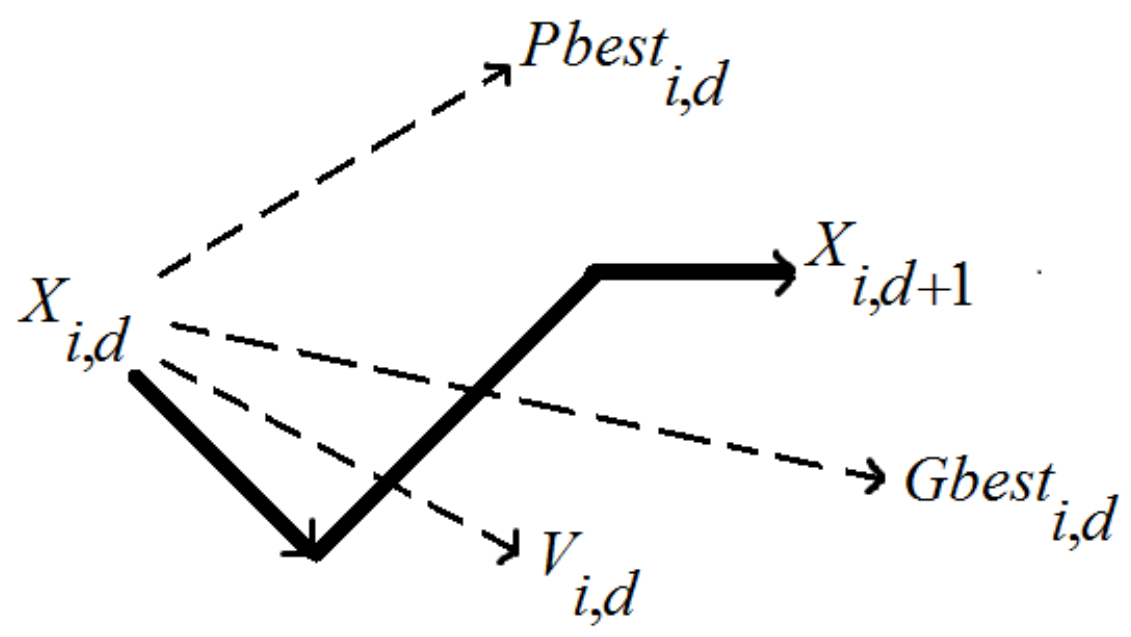

The mathematical formulation to update the velocity is as follows:

$$
V_{i}(d+1)=\omega V_{i}(d+1)+c_{1} r_{1}\left(X_{\text {pbest }_{i}}(d)-X_{i}(d)\right)+c_{2} r_{2}\left(X_{\text {gbest }}(d)-X_{i}(d)\right)
$$


where $\omega$ presents the inertia weights, $c_{1}$ and $c_{2}$ are random variables representing cognitive and social scaling parameters. $r_{1}$ and $r_{2}$ are random variables uniformly distributed in $[0,1] . d$ is the dimensional variable. Therefore, the new particle position is calculated as follows:

$$
X_{i}(d+1)=X_{i}(d)+V_{i}(d+1)
$$

\section{Methodology}

The study uses both primary and secondary research methods. First, a thorough literature review is undertaken in order to develop a conceptual framework of SMEs sustainability structure. This study considers demand management, supply management, internal process management, environmental and social management as input variables, and turnover, business growth and environmental performance as output variables. Second, a questionnaire has been formed to gather the perceptions of SMEs managers and owners on sustainability practices and performances through survey method. The questionnaire is enclosed in Appendix A. Third, an algorithm has been developed using combined NN and MPSO method to formulate the optimal structure of sustainable SMEs. Forth, data has been gathered from 53 French SMEs from Normandy area, and 30 SMEs from Midlands in the UK using the questionnaire survey. The proposed algorithm is applied to the above two regions using the data gathered in the surveys in order to develop sustainable SMEs' structure.

\section{The Proposed Algorithm}

The proposed algorithm contains three steps. In the first step, we train our data to generate the best $\mathrm{NN}$ for the turnover, the environmental management and the business growth. In the second step, we adopt weighted sum method to transform a multi-objective problem into uni-objective problem. Therefore, we apply the values of the different weights to the objectives generated by the NN algorithm. Once the problem is transformed into a uni-objective problem, we use the PSO to find the best suitable combination of inputs that generates the highest weighted sum of turnover, environmental management and business growth. We note that the set of weights is defined as $\left(\lambda_{k} ; k=1, \ldots, M\right)$. (See Figure 3) 
Figure 3. Proposed solution

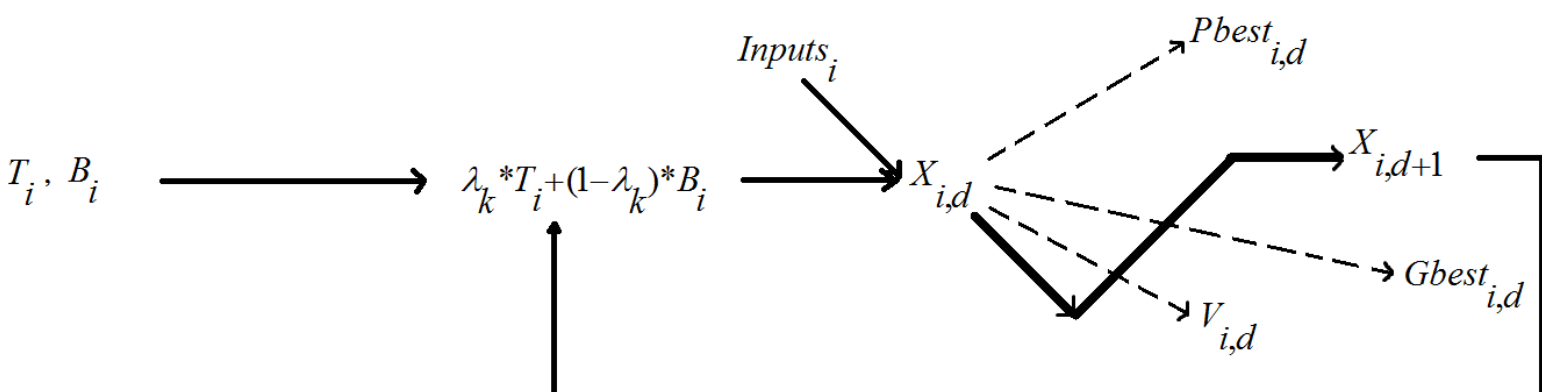

\section{Part 1: Neural Network}

- Run the NN algorithm to calculate activation outputs

\section{Neural Network algorithm:}

Step 1: Initialize inputs and outputs desired for the three objectives (These values are provided from the responses on the questionnaire)

Step 2: For 1 to the number of inputs $(N)$

- Calculate intermediary outputs

- $\quad$ Adjust weights by using the back propagation method

- Calculate activation outputs

Step 3: Go to step 2 until stopping criteria are satisfied.

\section{Part 2: Weighted sum method \& PSO}

For $k=1$ to the number of weights $(M)$

- Apply the weighted sum method.

- $\quad$ Run the PSO algorithm to find best structure for different weights.

\section{PSO algorithm:}

Step 1: Initialize all particle positions and velocities

Step 2: For each particle:

- Evaluate analysis function with used weights determined by $\mathrm{NN}$ algorithm in step 2

- Evaluate values of its previous best position and global best position

- Update particle velocities and positions

Step 3: Go to step 3 until stopping criteria are satisfied. 


\section{Results and Implications}

The above algorithm has been applied in two regions - Normandy in France and Midlands in the UK through collection of data from random SMEs using the questionnaire (appendix A) survey. Table 1 and 2 present the survey responses on observed inputs and outputs from the two regions along with the results of turnover, business growth and environmental performance of the SMEs derived through NN algorithm. The observed inputs: environmental practices, demand management, supply management, internal process management and social management are provided in columns 5, 6, 7, 8 and 9 respectively. The observed outputs - turnover, business growth and environmental performance are in columns 2, 3, and 4 respectively. The last columns 10,11 and 12 are the results obtained after training the NN for the French and the UK databases. For example in table 1, the observed turnover, business growth and the environmental management for the DMU1 are equal to 4.5, 4 and 3.667. The generated values by the $\mathrm{NN}$ for the same variables are $4.549,4.087$ and 3.831. Table 3 presents the results of the NN when we consider both databases (French and the UK). The validation of the results of NN analysis is carried out through deriving Mean Absolute Percentage Error (MAPE) for each output variable for French, UK and combined data. All the MAPEs are within the desired limits.

As described in the previous section, table 4 provides optimal solutions for weighted sum problems considering different lambda values (See Figure 4). These solutions are Pareto efficient configurations regarding three outputs (i.e. turnover, business growth and environmental performance). Row 1 of table 4, for example, shows that the French SMEs' configuration with respect to environmental, demand, supply, internal process and social management are 3.54, 1, 2.59, 1 and 4 respectively along with outputs - turnover, business growth and environmental performance as $2.711,1.697$, and 3.497 respectively is a Pareto efficient for considering importance of turnover, business growth and environmental performance as $20 \%, 30 \%$ and $50 \%$ respectively. The corresponding optimal solution is 2.7998 . The other rows of table 4 depict different possible combinations of importance of output variables. For French SMEs table 4 depicts various observations. French SMEs can achieve best sustainability solution with $10 \%$ importance in turnover, $10 \%$ in business growth and $80 \%$ in environmental performance. They are likely to achieve overall lower sustainability performance if they emphasize on turnover compared to other two output criteria. However, emphasize on business growth is likely to achieve moderate overall sustainability for French SMEs. Table 5 depicts results for the UK SMEs. This shows with $80 \%$ importance in business growth is likely to produce the best sustainability whereas $80 \%$ importance to environmental performance might produce the worst sustainability result, which is a contrast from the French SMEs outcomes. The table 6 combines French and UK companies' data, which depicts that the combined emphasize on turnover and business growth are likely produce the best sustainability result but only emphasize on business growth might produce worst result. 
Figure 4. Lambda values

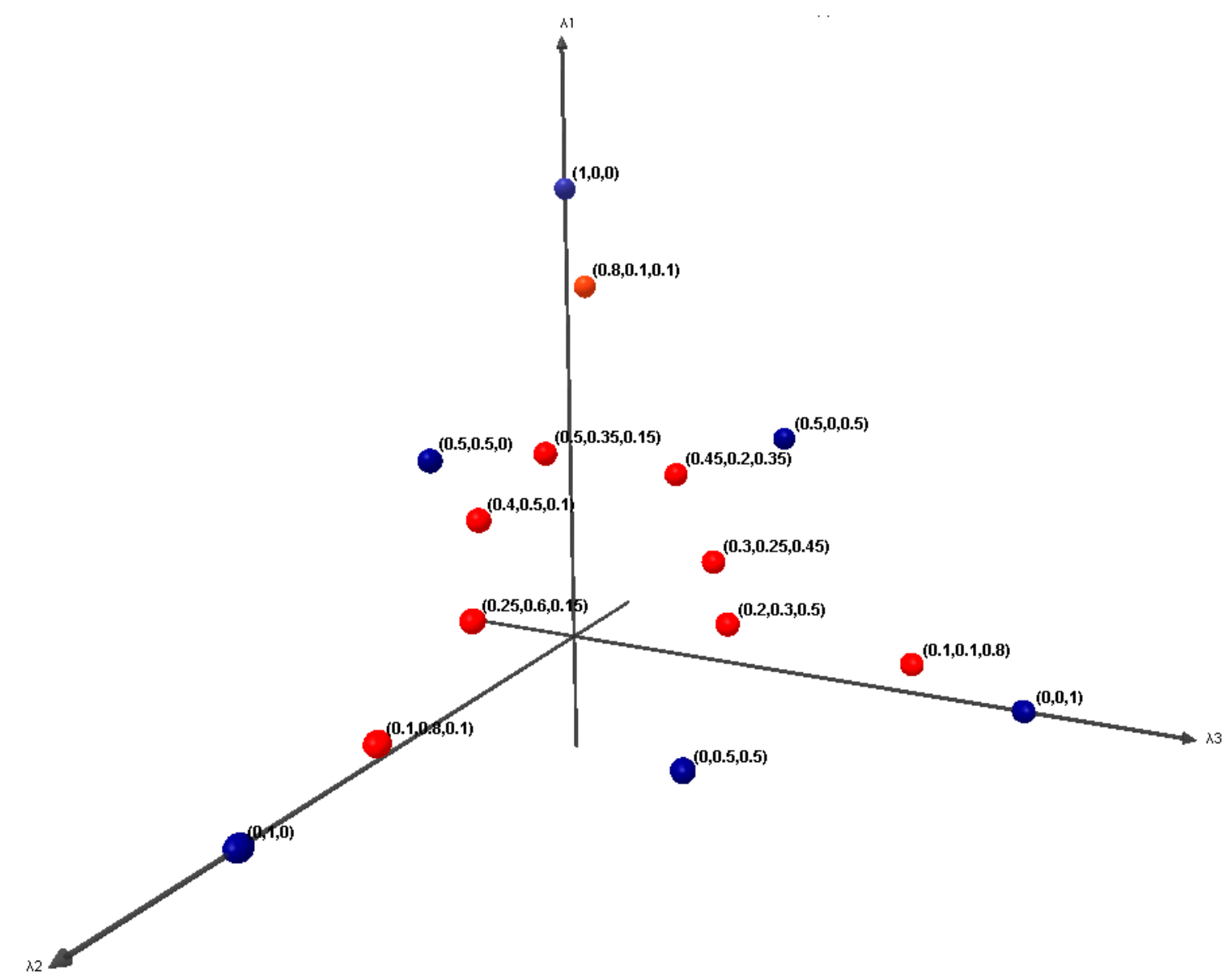

As per the PSO analysis (table 4) the optimal structure (with importance of $20 \%$ on Turnover, $30 \%$ on business growth and 50\% on environmental performance) of SMEs in Normandy, France with respect to environmental practices, demand management, supply management, internal process management and social management is $3.54,1,2.59,1$, and 4 respectively. This would likely to result optimal turnover, business growth and environmental performance as $2.711,1.697$, and 3.497 respectively. If we compare these results with the observed data of specific SME as gathered through survey interviews, we can derive the improvement measures. As for example, SME1 in France has the following observed data (second row of table 7a) and optimal SME structure in the region (third row of table 7a). The forth row briefly explains the improvement measures. If the same SME intends to achieve best optimum sustainability results they have to emphasize on environmental performance $(80 \%)$, over turnover $(10 \%)$ and business growth $(10 \%)$. The improvement measures in this circumstance will be altered as shown in table $7 \mathrm{~b}$. Similarly, table $8 \mathrm{a}$ and $8 \mathrm{~b}$ show the improvement measures for SME1 of the UK for achieving optimal sustainability performance for $20 \%$ importance in turnover, $30 \%$ importance in business growth and 50\% importance in environmental performance, and for $10 \%$ importance in 
turnover, $80 \%$ importance in business growth and $10 \%$ importance in environmental performance (best optimal) solution respectively. If this SME intends to make amendments in percentage of business objectives (in line with business environment) they are expected to undertake different improvement measures. The improvement measures could be derived considering the results from table 4 for the French SMEs, and table 5 for the UK SMEs with the consideration of various combinations of importance of output criteria in line with business environment.

\section{Advantages and Limitations of the proposed combined neural network (NN) and particle swam optimization (PSO)}

The objective of this study is to reveal the optimal structure of SMEs to achieve sustainability through most appropriate balance among economic, environmental and social performance. The study considers environmental practices, demand management, supply management, internal process management, and social management as input and turnover, business growth and environmental performance as output criteria for developing and testing most appropriate sustainability structure of SMEs. These criteria might vary across industries, geographical locations and over the period. In this study, we have adopted primary research approach, where we have gathered information on the criteria through questionnaire survey from the concerned stakeholders. Input criteria are subjective and we have adopted qualitative survey method using $1-5$ Likert scale. Although the output criteria are objective we decided to gather information in 1-5 Likert scale through perception survey of the managers of the SMEs in order to keep parity of data collection between input and output criteria. The entire research could be undertaken using secondary information through an agreed scale of measurement. This limitation could easily be overcome by emphasizing gathering as much information as possible through secondary sources (e.g. published data) and adopting primary research method for the criteria for which it is impossible to get secondary data sources.

We have considered the combined NN and PSO approach to derive optimal structure of SMEs for achieving sustainability as this has advantages over other methods as stated earlier. However, there are other possible approaches that could have been undertaken instead, which would have resulted almost similar outcomes with a few constraints. The following paragraph briefly discusses a few alternative methods that could have been used instead of NN and PSO approach along with their pros and cons.

Multiple criteria decision making (MCDM) approaches (e.g. the analytic hierarchy process, the analytic network process, fuzzy theory etc.) help rank alternatives using multiple criteria (both objective and subjective) in multiple hierarchy (e.g. criteria, sub-criteria, and proxies), and in conflicting scenarios (i.e. each criterion can favour different alternative). This approach is suitable for benchmarking small number of SMEs on their sustainability performance but unsuitable for developing most optimal sustainability configuration of group of SMEs. Goal programming is another MCDM method that can 
formulate optimal structure of SMEs through setting up of a few goals / targets but this needs also objective information to model objective function and constraints to derive the variables (inputs and outputs). Data Envelopment Analysis (DEA) can also be used to model sustainability performance of SMEs, which enables segregate efficient and inefficient SMEs, and suggests improvement measures for the inefficient SMEs through benchmarking with the most appropriate one. The efficient SMEs could be considered as having optimal structure but they are mostly locally optimized than globally. Structural equation modelling (SEM) is another approach that helps SMEs to achieve sustainability. It helps develop relationship among the criteria and sub-criteria through regression modelling. Although it facilitates to improve sustainability performance by identifying the root causes of superior sustainability performance but fails to depict an optimal SMEs' structure.

The proposed combined NN and PSO approach that facilitates to develop optimal structure for sustainable SMEs has a few more limitations. Optimal structure of SMEs depends on the sample size, importance of the output criteria and accuracy of data gathered from the sample SMEs. This limitations could be overcome by selecting most appropriate sample, scientifically deriving the importance of the criteria and selecting the interviewees carefully to reduce biasness. Additionally, deriving the means for improvement for each participating SME could be challenging. However, engaging with the concerned SME's representatives and jointly deriving solutions could be the way forward.

As the criteria for sustainability practices and performances are subjective the most appropriate method would be one that can handle subjectivity and convert them into objective information. The combined $\mathrm{NN}$ and PSO approach can fulfil this requirement by converting survey responses in $1-5$ scale to objective numbers. Additionally, it enables reveal optimal structure of SMEs through determining importance of the output criteria and vis a vis deriving desired inputs and outputs.

Similar approach could be adopted in other qualitative research, where the objective is to achieve a few predetermined targets.

However, the main advantage of the approach proposed in this paper it is capability to get the benefits of optimization algorithms without available explicit functional representation. The $\mathrm{NN}$ is taking over and feeds the optimization model with the needed data. The methodology could be applied to similar situations in quality management and many other fields of social sciences.

\section{Discussion and conclusion}

Small and medium sized enterprises (SMEs) are the backbone of any economy as $30-40 \%$ of GDP is contributed by SMEs in any economy. However, their sustainability is challenging due to intense competition and additionally, their environmental and social performances are also not impressive as they require to cut corner everywhere to emphasize on their economic sustainability. Prior researches (e.g. Bourlakis et al. 2014; Dey et al. 2013, Bhattacharya et al. 2015) have proposed several sustainability performance measurement models that enable measure not only individual SMEs 
sustainability performance but also entire supply chain sustainability performance could be derived. These help both SMEs' owners and managers, and policymakers to suggest improvement measures through standalone performance measurement or benchmarking with the best in the industry and geographical location. However, achieving sustainability through performance measurement has several shortcomings - it could consider a few criteria only, and there are also limitations in number of alternatives being analyzed. On the other hand, there are large number of studies (e.g. Huang et al. 2015) that build relationship using statistical techniques between upstream and downstream criteria for sustainability performance. Additionally, there are researches that reveal characteristics, and issues and challenges of sustainable supply chain practices of SMEs (e.g. Johnson 2015; Govindan et al. 2014; Trianni et al. 2016). They are important to suggest improvement measures to SMEs. However, they are predictive in nature and may not be quite accurate for specific SME. Developing optimal structure of SMEs for achieving sustainability within a geographical location and a specific industry with the consideration of economic, environmental and social criteria help SMEs to achieve sustainability objectively by dynamically measuring their performance and suggesting improvement measures. In summary, the literature on SMEs sustainability covers three broad areas - enhancing sustainability performance of SMEs' supply chain, studies on the impact of various sustainability criteria on business performance, and characteristics of SMEs' supply chain. They are important and significant in furthering knowledge on sustainability performance enhancement of SMEs' supply chain but lack providing holistic measures for improving each SME's sustainability performance objectively. The challenges multiply as the criteria for sustainable supply chain performance measurement is both subjective and objective and conflicting in nature. This requires primary data collection by engaging with representatives of SMEs within a region along with interacting with the policymakers of the specific region. This calls for a new framework of data collection, analysis and interpretation that in one hand develops a diagnostic tool with the consideration of supply chain sustainability practices and performances, and on the other hand derives improvement measures objectively. This research presents a new heuristic using neural network and particle swam optimization model. This enables to derive optimal structure of SMEs within a specific region in line with its business environment. This is beneficial to both policymakers and individual SMEs' owners and managers as both could get information on current state of SMEs' sustainable supply chain and means for improving SMEs' supply chain sustainability. Knowledge on optimal structure of SMEs enables the SME owners to analyze and derive which practices they are likely to enhance or reduce in order to achieve desired optimal sustainability performance (e.g. appropriate combination of turnover, business growth and environmental performance). Optimal structure of SMEs within a region enables policymakers with various information on SMEs practices and performances that leads to achieve greater sustainability. This facilitates them to make budget and other resource allocation decisions within the region that is likely to help achieve greater sustainability of SMEs within that region. Additionally, this helps to 
benchmark SMEs sustainability performance with the best in the region, which help to implement the

Theoretically this study contributes a particle swam optimization (PSO) model for sustainability analysis of SMEs through developing optimal sustainability structure of SMEs within a region. According to authors' knowledge, this is the first application of PSO approach in analyzing supply chain sustainability. The proposed model has been applied in two regions of two countries - Normandy in France and Midlands in the UK. The results depict various interesting findings that reveal the robustness of the model in terms of considering varied data, method of data collection, engagement of stakeholders and ability of undertaking sensitivity analysis. In fact, this shows that the model could be used in varied settings in order to improve SMEs sustainability. The proposed model has advantages over the contemporary methods (e.g. conventional MCDM techniques (Dey et al. 2013), DEA approach (Petridis and Dey, 2018) and statistical analysis (Malesios et al. 2018)) with respect to its robustness, objectivity, and possibility of undertaking sensitivity analysis, accuracy, ease to apply and its user friendliness. Additionally, the model is flexible / resilient with an additional feature of incorporating importance of criteria in line with business environment. This enables deriving numerous optimal structure of SMEs as per the business needs allowing both individual SMEs' owners and managers to make decision of SMEs sustainability practices and performance. Also the policymaker's takeaway deep understanding of the issues and challenges of SMEs in their region in order to facilitate overall improvement of sustainability of SMEs within a region.

The proposed method considers multiple objectives along with multiple criteria, which are both subjective and objectives. Data could be collected both from primary and secondary sources using questionnaire survey and conducting interviews. The selection of interviewees (number and experience) is important as the accuracy of the results will depend on this. Various sampling criteria could be chosen to undertake this study in varied regions.

The proposed combined NN and PSO method for sustainable SMEs sustainability structure development has a few shortcomings - considering explicit criteria and sub-criteria, selection of interviewees, considerations of various scenarios (importance of the criteria) and deriving results accordingly, interpreting the results and deciding on improvement measures, convincing all the stakeholders on decisions when the results have been interpreted from various assumptions, and correlating business environment with SMEs' emphasize on sustainability criteria. In view of the above, there are a few scopes of furthering this research through applications in other regions, considering other criteria and sub-criteria, and using different modelling approaches. Additionally, NN and PSO model could be compared with other methods (e.g. conventional MCDM techniques - the AHP and ANP, Fuzzy, Goal Programming, DEA, other statistical methods etc.) 
In summary, achieving SMEs' supply chain sustainability is challenging but doable. This requires effort from both policymakers and individual SME owners and managers. Deriving the most appropriate tradeoff among economic, environmental and social criteria could form the optimal structure of SMEs. However, this requires to be dynamic in line with the business environment. Various economic, environmental and social practices could be related to turnover, business growth and environment performance of SMEs to develop a conceptual sustainable structure for SMEs. Data collection on the relationships among practices and performances within a region and running PSO algorithm allows to derive most optimal structure of SMEs within a specific region for different scenarios (e.g. for varied importance on performances criteria - turnover, business growth and environmental performance). This enables to derive improvement measures on SMEs' performance dynamically to achieve greater sustainability.

\section{References}

Abdelaziz, F, B, \& El-Baz, H, (2010, March), An optimization model based on Neural Network and Particle Swarm: an application case from the UAE, InEngineering Systems Management and Its Applications (ICESMA), 2010 Second International Conference on (pp, 1-6), IEEE,

Bourlakis, M., Maglaras, G. Aktasc, E., Gallear, D., Fotopoulos, C., (2014), Firm size and sustainable performance in food supply chains: Insights from Greek SMEs, International Journal of Production Economics, Volume 152, June 2014, Pages 112-130.

Bhattacharya, A., Mohapatra, P., Kumar, V., Dey, P.K., Brady, M. and Tiwari, M.K., (2014) "Green supply chain performance measurement using fuzzy ANP-based balanced scorecard: a collaborative decision-making approach". Production Planning \& Control Manuscript, Vol. 25 Issue 8, $698-714$.

Charnes, A, \& Cooper, W, W, (1963), Deterministic equivalents for optimizing and satisficing under chance constraints, Operations research, 11(1), 18-39,

Charnes, A, Cooper, W, W, \& Ferguson, R, O, (1955), Optimal estimation of executive compensation by linear programming, Management science, 1(2), 138-151,

Craig, R, Carter D, \& Rogers, S, (2008), A framework of sustainable supply chain management: moving toward new theory, International Journal of Physical Distribution \& Logistics Management, Vol, 38 Issue: 5, pp,360-387,

Dey, P K. Cheffi, W. and Nunes, B. (2013), Managing supply chain integration: contemporary approaches and scope for further research, Production planning and control, Guest editorial, 24 $(8-9), 653-657$.

Eberhart, R, C, \& Kennedy, J, (1995, October), A new optimizer using particle swarm theory, In Proceedings of the sixth international symposium on micro machine and human science (Vol, 1, pp, $39-43)$, 
Gass, S, \& Saaty, T, (1955), The computational algorithm for the parametric objective function, Naval research logistics quarterly, 2(1 $\square 2), 39-45$,

Govindan, K, Kaliyan, M,, Kannan, D, \& Haq, A,N, (2014), Barriers analysis for green supply chain management implementation in Indian industries using analytic hierarchy process, IJPE, Volume 147, Part B, January 2014, Pages 555-568,

Haimes, Y, Y, Ladson, L, S, \& Wismer, D, A, (1971), Bicriterion formulation of problems of integrated system identification and system optimization, IEEE Transactions on Systems Man and Cybernetics, (3), 296,

Hu, Y, H, \& Hwang, J, N, (Eds,), (2001), Handbook of neural network signal processing, CRC press, Looney, C, G, (1997), Pattern recognition using neural networks: theory and algorithms for engineers and scientists, Oxford University Press, Inc,,

Huang, X., Tan, B L., Ding, X., (2015), An exploratory survey of green supply chain management in Chinese manufacturing small and medium-sized enterprises: Pressures and drivers, Journal of Manufacturing Technology Management, Vol. 26 Issue: 1, pp.80-103.

Jenkins, H, (2009), A business opportunity model of corporate social responsibility for small and medium sized enterprise, Business Ethics: A European Review, Vol 18 (1), 21 - 36,

Johnson, M P., (2015), Sustainability Management and Small and Medium-Sized Enterprises: Managers' Awareness and Implementation of Innovative Tools, Corporate Social Responsibility and Environmental Management, Volume 22, Issue 5, Pages 271-285.

Jayaram, J, Dixit, M, \& Motwani, J, (2014), Supply chain management capability of small and medium sized family businesses in India, A multiple case study approach, IJPE Volume 147, Part B, January 2014, Pages 472-485,

Kerr, I R., (2006), Leadership strategies for sustainable SME operations, Business Strategy and the Environment, volume 15, Issue 1, $30-39$.

KPMG (2005), KPMG International Survey of Corporate Responsibility Reporting 2005, University of Amsterdam, Amsterdam,

Looney, C. G. (1997), Pattern recognition using neural networks: theory and algorithms for engineers and scientists, Oxford University Press, Inc. New York, NY, USA (C1997, ISBN:0-19-507920-5

Malesios, C., Skouloudis, A., Dey, P. K., Abdelaziz, F. B., Kantartzis, A. and Evangelinos, K. (2018) The impact of SME sustainability practices and performance on economic growth from a managerial perspective: Some modeling considerations and empirical analysis results. Business Strategy and the Environment. ISSN 1099-0836 (In Press)

Norgard, P, M, Ravn, O,, Poulsen, N, K,, \& Hansen, L, K, (2000), Neural Networks for Modelling and Control of Dynamic Systems-A, Practitioner's Handbook,

Petridis, K., and Dey, P. K., (2018), Measuring incineration plants' performance using combined data envelopment analysis, goal programming and mixed integer linear programming, Annals of Operations Research (in Press) 
Seuring, S., Sarkis, J., Müller, M., Rao, P., (2008), Sustainability and supply chain management - An introduction to the special issue, Journal of Cleaner Production, Volume 16, Issue 15, Pages 15451551.

Trianni, A., Cagno, E., Farné, S., (2016), Barriers, drivers and decision-making process for industrial energy efficiency: A broad study among manufacturing small and medium-sized enterprises, Applied Energy, Volume 162, Pages 1537-1551.

Walker, H and Preuss, L., (2008), Fostering sustainability through sourcing from small businesses: public sector perspectives, Journal of Cleaner Production, Volume 16, Issue 15, Pages 1600-1609 


\section{Tables}

\begin{tabular}{|c|c|c|c|c|c|c|c|c|c|c|c|}
\hline \multirow[b]{2}{*}{ DMUs } & \multicolumn{3}{|c|}{ Observed Outputs } & \multicolumn{5}{|c|}{ Observed Inputs } & \multicolumn{3}{|c|}{$\begin{array}{c}\text { Values generated by the NN } \\
\text { algorithm }\end{array}$} \\
\hline & Outp1 & Outp2 & Outp3 & Inp1 & Inp2 & Inp3 & Inp4 & Inp5 & G.O.1 & G.0.2 & G.O.3 \\
\hline SME 1 (FR) & 4,5 & 4 & 3,667 & 4,000 & 4,167 & 3,000 & 1,700 & 3,000 & 4,549 & 4,087 & 3,831 \\
\hline SME 2 (FR) & 0,5 & 1 & 2,000 & 1,833 & 4,500 & 2,667 & 1,400 & 2,000 & 0,519 & 0,979 & 2,058 \\
\hline SME 3 (FR) & 0,5 & 1 & 2,000 & 1,833 & 3,167 & 2,667 & 1,900 & 2,000 & 0,507 & 0,957 & 1,927 \\
\hline SME 4 (FR) & 3 & 5 & 2,000 & 1,333 & 4,000 & 2,667 & 1,200 & 2,500 & 3,042 & 4,852 & 2,021 \\
\hline SME 5 (FR) & 1 & 2 & 3,000 & 2,167 & 4,333 & 2,667 & 1,800 & 2,000 & 1,007 & 1,993 & 3,143 \\
\hline SME 6 (FR) & 0,5 & 2 & 2,000 & 1,167 & 3,000 & 2,667 & 1,300 & 1,000 & 0,509 & 1,929 & 1,930 \\
\hline SME 7 (FR) & 3 & 5 & 4,333 & 3,833 & 5,000 & 3,000 & 3,300 & 3,500 & 2,988 & 5,000 & 4,648 \\
\hline SME 8 (FR) & 0,5 & 1 & 1,333 & 1,167 & 1,000 & 2,000 & 1,000 & 1,000 & 0,523 & 0,938 & 1,200 \\
\hline SME 9 (FR) & 0,5 & 1 & 2,333 & 2,000 & 3,167 & 2,667 & 2,500 & 2,000 & 0,486 & 0,953 & 2,291 \\
\hline SME 10 (FR) & 0,5 & 1 & 2,667 & 1,833 & 2,167 & 2,667 & 1,800 & 2,000 & 0,516 & 0,947 & 2,571 \\
\hline SME 11 (FR) & 3 & 1 & 2,667 & 1,833 & 4,167 & 2,667 & 1,600 & 2,000 & 3,018 & 0,975 & 2,766 \\
\hline SME 12 (FR) & 0,5 & 1 & 2,667 & 2,167 & 2,667 & 2,667 & 1,800 & 2,000 & 0,515 & 1,001 & 2,612 \\
\hline SME 13 (FR) & 1 & 2 & 3,333 & 3,000 & 2,000 & 2,000 & 3,000 & 3,000 & 0,989 & 1,953 & 3,250 \\
\hline SME 14 (FR) & 2,5 & 5 & 4,000 & 4,000 & 2,167 & 2,667 & 3,200 & 4,000 & 2,513 & 5,000 & 3,994 \\
\hline SME 15 (FR) & 2,5 & 5 & 3,667 & 4,000 & 3,667 & 2,667 & 3,200 & 4,000 & 2,505 & 5,000 & 3,769 \\
\hline SME 16 (FR) & 0,5 & 1 & 3,000 & 3,333 & 4,833 & 2,000 & 3,000 & 3,000 & 0,474 & 1,069 & 3,147 \\
\hline SME 17 (FR) & 0,5 & 2 & 3,000 & 3,333 & 2,833 & 2,667 & 3,000 & 3,000 & 0,492 & 2,038 & 2,965 \\
\hline SME 18 (FR) & 4 & 1 & 3,333 & 3,167 & 3,500 & 2,667 & 3,000 & 3,000 & 3,995 & 1,032 & 3,403 \\
\hline SME 19 (FR) & 0,5 & 1 & 2,000 & 1,833 & 2,167 & 2,667 & 1,400 & 1,500 & 0,521 & 0,993 & 1,833 \\
\hline SME 20 (FR) & 4 & 2 & 3,333 & 3,667 & 4,500 & 2,667 & 3,000 & 3,000 & 3,991 & 2,098 & 3,489 \\
\hline SME 21(FR) & 0,5 & 1 & 3,000 & 2,833 & 3,833 & 2,667 & 1,800 & 2,500 & 0,521 & 1,060 & 3,079 \\
\hline SME 22 (FR) & 1 & 2 & 3,333 & 3,167 & 3,667 & 2,667 & 1,700 & 2,000 & 1,018 & 2,071 & 3,426 \\
\hline SME 23 (FR) & 0,5 & 3 & 3,667 & 3,167 & 4,333 & 3,000 & 2,000 & 2,000 & 0,506 & 3,047 & 3,866 \\
\hline SME 24 (FR) & 0,5 & 5 & 3,333 & 2,167 & 4,333 & 2,667 & 1,800 & 2,000 & 0,506 & 4,950 & 3,513 \\
\hline SME 25 (FR) & 2,5 & 1 & 2,667 & 3,167 & 2,500 & 2,667 & 2,800 & 3,000 & 2,505 & 1,025 & 2,568 \\
\hline SME 26 (FR) & 2 & 4 & 4,333 & 4,500 & 3,167 & 3,000 & 4,000 & 4,000 & 1,982 & 4,075 & 4,452 \\
\hline SME 27 (FR) & 0,5 & 1 & 1,333 & 1,167 & 1,000 & 2,000 & 1,000 & 1,000 & 0,523 & 0,938 & 1,200 \\
\hline SME 28 (FR) & 1,5 & 2 & 3,333 & 3,500 & 4,667 & 2,667 & 3,000 & 3,000 & 1,485 & 2,080 & 3,509 \\
\hline SME 29 (FR) & 0,5 & 1 & 2,667 & 2,833 & 1,000 & 2,667 & 1,600 & 2,000 & 0,533 & 1,078 & 2,437 \\
\hline SME 30 (FR) & 0,5 & 1 & 2,333 & 2,500 & 2,167 & 2,667 & 1,700 & 2,000 & 0,522 & 1,041 & 2,186 \\
\hline SME 31 (FR) & 0,5 & 1 & 3,333 & 3,000 & 1,667 & 2,667 & 1,700 & 2,000 & 0,526 & 1,093 & 3,236 \\
\hline SME 32 (FR) & 0,5 & 2 & 2,667 & 2,833 & 2,667 & 2,667 & 2,900 & 2,000 & 0,476 & 2,038 & 2,593 \\
\hline SME 33 (FR) & 0,5 & 1 & 1,667 & 1,833 & 3,167 & 2,667 & 1,700 & 1,500 & 0,505 & 0,989 & 1,559 \\
\hline SME 34 (FR) & 0,5 & 2 & 3,333 & 3,000 & 4,000 & 2,667 & 3,000 & 3,000 & 0,485 & 2,005 & 3,456 \\
\hline SME 35 (FR) & 3,5 & 5 & 3,333 & 3,167 & 3,667 & 2,667 & 3,000 & 3,000 & 3,493 & 5,000 & 3,420 \\
\hline SME 36 (FR) & 1,5 & 3 & 3,667 & 3,500 & 2,500 & 3,000 & 3,000 & 3,500 & 1,509 & 3,008 & 3,675 \\
\hline SME 37 (FR) & 1 & 2 & 3,667 & 3,333 & 3,667 & 3,000 & 3,200 & 3,500 & 0,994 & 1,998 & 3,791 \\
\hline SME 38 (FR) & 0,5 & 3 & 2,000 & 2,167 & 3,333 & 2,667 & 2,100 & 1,000 & 0,481 & 2,993 & 1,936 \\
\hline SME 39 (FR) & 0,5 & 1 & 1,333 & 1,167 & 4,333 & 2,667 & 1,200 & 1,000 & 0,506 & 0,939 & 1,318 \\
\hline SME 40 (FR) & 1 & 1 & 2,000 & 2,167 & 4,167 & 3,000 & 2,300 & 1,000 & 0,974 & 1,018 & 2,022 \\
\hline SME 41 (FR) & 3,5 & 5 & 3,333 & 3,167 & 2,833 & 2,667 & 3,000 & 3,000 & 3,497 & 4,986 & 3,339 \\
\hline SME 42 (FR) & 0,5 & 1 & 1,333 & 1,167 & 1,333 & 2,333 & 1,200 & 1,000 & 0,517 & 0,936 & 1,300 \\
\hline SME 43 (FR) & 3 & 3 & 3,333 & 3,500 & 3,167 & 2,667 & 2,900 & 3,000 & 3,000 & 3,062 & 3,364 \\
\hline SME 44 (FR) & 0,5 & 1 & 3,333 & 2,833 & 3,500 & 3,000 & 3,000 & 3,500 & 0,499 & 0,918 & 3,416 \\
\hline SME 45 (FR) & 0,5 & 1 & 2,667 & 2,167 & 5,167 & 3,000 & 2,900 & 4,000 & 0,500 & 0,761 & 2,853 \\
\hline SME 46 (FR) & 1 & 3 & 4,000 & 4,000 & 4,333 & 3,000 & 3,900 & 4,000 & 0,975 & 3,026 & 4,207 \\
\hline SME 47 (FR) & 5 & 1 & 2,667 & 2,500 & 3,833 & 3,000 & 1,500 & 1,000 & 5,000 & 1,021 & 2,726 \\
\hline SME 48 (FR) & 5 & 2 & 2,333 & 2,167 & 5,000 & 2,667 & 1,600 & 1,000 & 5,000 & 1,973 & 2,469 \\
\hline SME 49 (FR) & 0,5 & 1 & 3,000 & 2,333 & 3,333 & 2,667 & 3,000 & 2,500 & 0,477 & 0,933 & 3,037 \\
\hline SME 50 (FR) & 0,5 & 3 & 3,333 & 3,167 & 4,000 & 2,667 & 2,700 & 2,500 & 0,487 & 3,054 & 3,454 \\
\hline SME 51 (FR) & 1 & 3 & 2,000 & 1,833 & 2,500 & 2,667 & 1,400 & 1,500 & 1,021 & 2,967 & 1,865 \\
\hline SME 52 (FR) & 0,5 & 1 & 2,000 & 2,333 & 3,667 & 3,000 & 2,300 & 1,000 & 0,476 & 1,034 & 1,970 \\
\hline SME 53 (FR) & 0,5 & 1 & 2,667 & 2,833 & 2,500 & 2,667 & 1,800 & 3,000 & 0,537 & 1,026 & 2,579 \\
\hline SME 54 (FR) & 1,5 & 1 & 3,000 & 3,333 & 3,333 & 2,667 & 2,900 & 3,000 & 1,495 & 1,060 & 3,014 \\
\hline & & & & & & & & PE(\%) & 2,121 & 3,345 & 3,682 \\
\hline
\end{tabular}

Table 1. French companies results

Outp1: Turnover, Outp2: Business growth, Outp3: Environmental management, Inp1: Environmental practices, Inp2: Demand management, Inp3: Supply management, Inpu4: Internal process management, Inp5: Social management, G.O.1: Turnover, G.O.2: Business growth and G.O.3: Environmental management. We will use these abbreviations in all tables 


\begin{tabular}{|c|c|c|c|c|c|c|c|c|c|c|c|}
\hline \multirow[b]{2}{*}{ Compagnies } & \multicolumn{3}{|c|}{ Observed Outputs } & \multicolumn{5}{|c|}{ Observed Inputs } & \multicolumn{3}{|c|}{$\begin{array}{c}\text { Values generated by the NN } \\
\text { algorithm }\end{array}$} \\
\hline & Outp1 & Outp2 & Outp3 & Inp1 & Inp2 & Inp3 & Inp4 & Inp5 & G.0.1 & G.O.2 & G.O.3 \\
\hline SME 1 (UK) & 1 & 1 & 2,000 & 1,667 & 1,000 & 2,000 & 1,500 & 3,000 & 0,928 & 0,902 & 2,003 \\
\hline SME 2 (UK) & 1 & 3 & 2,000 & 2,000 & 2,333 & 1,667 & 1,500 & 2,000 & 1,017 & 3,037 & 1,995 \\
\hline SME 3 (UK) & 4 & 3 & 2,000 & 3,000 & 2,667 & 4,000 & 2,500 & 1,500 & 3,988 & 3,085 & 2,063 \\
\hline SME 4 (UK) & 0,5 & 2 & 1,000 & 1,000 & 1,333 & 1,667 & 1,000 & 1,500 & 0,472 & 1,938 & 0,896 \\
\hline SME 5 (UK) & 3 & 3 & 1,667 & 2,667 & 1,667 & 1,667 & 2,500 & 1,500 & 3,000 & 3,053 & 1,749 \\
\hline SME 6 (UK) & 0,5 & 2 & 1,333 & 1,333 & 1,000 & 1,667 & 1,000 & 1,000 & 0,461 & 1,944 & 1,296 \\
\hline SME 7 (UK) & 1,5 & 1 & 2,000 & 2,000 & 1,000 & 2,333 & 1,500 & 1,500 & 1,440 & 0,913 & 2,047 \\
\hline SME 8 (UK) & 2 & 3 & 2,000 & 2,000 & 2,667 & 3,000 & 2,500 & 2,000 & 1,997 & 3,051 & 1,958 \\
\hline SME 9 (UK) & 3 & 3 & 2,000 & 2,000 & 2,333 & 2,000 & 2,500 & 1,500 & 3,024 & 3,042 & 1,987 \\
\hline SME 10 (UK) & 0,5 & 1 & 1,667 & 1,667 & 1,333 & 2,333 & 1,500 & 2,500 & 0,437 & 0,907 & 1,644 \\
\hline SME 11 (UK) & 3 & 3 & 2,667 & 2,000 & 3,000 & 2,333 & 2,000 & 1,500 & 3,051 & 3,049 & 2,649 \\
\hline SME 12 (UK) & 2,5 & 4 & 2,000 & 2,667 & 2,333 & 2,667 & 2,500 & 2,500 & 2,488 & 4,122 & 2,048 \\
\hline SME 13 (UK) & 1 & 2 & 2,000 & 1,667 & 2,333 & 2,667 & 1,500 & 1,500 & 0,993 & 1,975 & 1,949 \\
\hline SME 14 (UK) & 1 & 3 & 2,667 & 1,333 & 2,667 & 2,667 & 1,500 & 4,000 & 0,981 & 3,026 & 2,571 \\
\hline SME 15 (UK) & 1,5 & 4 & 1,000 & 2,000 & 3,333 & 2,667 & 1,500 & 1,500 & 1,548 & 4,109 & 0,909 \\
\hline SME 16 (UK) & 2 & 3 & 3,000 & 2,667 & 4,000 & 2,667 & 1,500 & 1,500 & 2,086 & 3,079 & 3,026 \\
\hline SME 17 (UK) & 1,5 & 2 & 1,000 & 1,667 & 2,000 & 3,000 & 2,000 & 1,000 & 1,473 & 1,975 & 0,924 \\
\hline SME 18 (UK) & 1,5 & 1 & 1,333 & 1,333 & 2,000 & 2,333 & 1,500 & 1,500 & 1,491 & 0,904 & 1,239 \\
\hline SME 19 (UK) & 1,5 & 4 & 2,000 & 2,333 & 4,000 & 3,000 & 2,500 & 2,500 & 1,554 & 4,131 & 1,936 \\
\hline SME 20 (UK) & 4 & 2 & 2,000 & 2,667 & 2,000 & 2,667 & 2,500 & 2,500 & 3,983 & 2,005 & 2,062 \\
\hline SME 21(UK) & 0,5 & 1 & 1,000 & 1,333 & 2,667 & 1,333 & 1,000 & 1,500 & 0,550 & 0,905 & 0,881 \\
\hline SME 22 (UK) & 1 & 2 & 1,667 & 2,000 & 3,000 & 2,333 & 1,500 & 1,500 & 1,037 & 1,991 & 1,617 \\
\hline SME 23 (UK) & 0,5 & 3 & 1,000 & 1,000 & 2,000 & 1,667 & 1,500 & 1,000 & 0,509 & 3,003 & 0,868 \\
\hline SME 24 (UK) & 1 & 2 & 1,000 & 1,333 & 1,000 & 2,000 & 1,500 & 1,500 & 0,946 & 1,948 & 0,940 \\
\hline SME 25 (UK) & 2 & 1 & 2,000 & 2,333 & 2,333 & 2,333 & 1,500 & 1,500 & 2,011 & 0,937 & 2,028 \\
\hline SME 26 (UK) & 0,5 & 2 & 1,333 & 1,000 & 1,000 & 1,000 & 1,000 & 1,500 & 0,475 & 1,931 & 1,263 \\
\hline SME 27 (UK) & 4,5 & 5 & 3,000 & 3,333 & 3,000 & 3,333 & 3,000 & 3,000 & 4,509 & 5,000 & 3,115 \\
\hline SME 28 (UK) & 1,5 & 2 & 2,000 & 1,667 & 2,333 & 2,667 & 2,000 & 2,500 & 1,483 & 1,977 & 1,939 \\
\hline SME 29 (UK) & 2 & 3 & 3,000 & 2,333 & 3,000 & 2,333 & 1,500 & 2,000 & 2,039 & 3,057 & 3,031 \\
\hline SME 30 (UK) & 0,5 & 1 & 2,667 & 2,000 & 1,667 & 1,667 & 2,000 & 2,000 & 0,477 & 0,919 & 2,709 \\
\hline & & & & & & MAP & & & 3,11 & 3,56 & 3,95 \\
\hline
\end{tabular}

Table 2. UK companies results

\begin{tabular}{|c|c|c|c|c|c|c|c|c|c|c|c|}
\hline \multirow[b]{2}{*}{ Compagnies } & \multicolumn{3}{|c|}{ Observed Outputs } & \multicolumn{5}{|c|}{ Observed Inputs } & \multicolumn{3}{|c|}{$\begin{array}{c}\text { Values generated by the } \\
\text { NN algorithm }\end{array}$} \\
\hline & Outp1 & Outp2 & Outp3 & Inp1 & Inp2 & Inp3 & Inp4 & Inp5 & G.0.1 & G.0.2 & G.0.3 \\
\hline SME 1 (UK) & 1 & 1 & 2,000 & 1,667 & 1,000 & 2,000 & 1,500 & 3,000 & 0,998 & 0,990 & 1,999 \\
\hline SME 2 (UK) & 1 & 3 & 2,000 & 2,000 & 2,333 & 1,667 & 1,500 & 2,000 & 1,009 & 2,996 & 1,992 \\
\hline SME 3 (UK) & 4 & 3 & 2,000 & 3,000 & 2,667 & 4,000 & 2,500 & 1,500 & 3,997 & 2,996 & 2,016 \\
\hline SME 4 (UK) & 0,5 & 2 & 1,000 & 1,000 & 1,333 & 1,667 & 1,000 & 1,500 & 0,500 & 2,007 & 0,990 \\
\hline SME 5 (UK) & 3 & 3 & 1,667 & 2,667 & 1,667 & 1,667 & 2,500 & 1,500 & 3,033 & 2,976 & 1,703 \\
\hline SME 6 (UK) & 0,5 & 2 & 1,333 & 1,333 & 1,000 & 1,667 & 1,000 & 1,000 & 0,518 & 1,998 & 1,383 \\
\hline SME 7 (UK) & 1,5 & 1 & 2,000 & 2,000 & 1,000 & 2,333 & 1,500 & 1,500 & 1,517 & 0,988 & 2,075 \\
\hline SME 8 (UK) & 2 & 3 & 2,000 & 2,000 & 2,667 & 3,000 & 2,500 & 2,000 & 1,987 & 3,012 & 1,979 \\
\hline SME 9 (UK) & 3 & 3 & 2,000 & 2,000 & 2,333 & 2,000 & 2,500 & 1,500 & 3,005 & 3,000 & 2,012 \\
\hline SME 10 (UK) & 0,5 & 1 & 1,667 & 1,667 & 1,333 & 2,333 & 1,500 & 2,500 & 0,498 & 0,997 & 1,660 \\
\hline SME 11 (UK) & 3 & 3 & 2,667 & 2,000 & 3,000 & 2,333 & 2,000 & 1,500 & 2,992 & 3,007 & 2,682 \\
\hline SME 12 (UK) & 2,5 & 4 & 2,000 & 2,667 & 2,333 & 2,667 & 2,500 & 2,500 & 2,505 & 3,995 & 1,985 \\
\hline SME 13 (UK) & 1 & 2 & 2,000 & 1,667 & 2,333 & 2,667 & 1,500 & 1,500 & 0,993 & 2,009 & 2,010 \\
\hline SME 14 (UK) & 1 & 3 & 2,667 & 1,333 & 2,667 & 2,667 & 1,500 & 4,000 & 0,952 & 3,013 & 2,569 \\
\hline SME 15 (UK) & 1,5 & 4 & 1,000 & 2,000 & 3,333 & 2,667 & 1,500 & 1,500 & 1,489 & 4,013 & 0,922 \\
\hline SME 16 (UK) & 2 & 3 & 3,000 & 2,667 & 4,000 & 2,667 & 1,500 & 1,500 & 1,998 & 2,999 & 2,998 \\
\hline SME 17 (UK) & 1,5 & 2 & 1,000 & 1,667 & 2,000 & 3,000 & 2,000 & 1,000 & 1,498 & 2,011 & 0,997 \\
\hline SME 18 (UK) & 1,5 & 1 & 1,333 & 1,333 & 2,000 & 2,333 & 1,500 & 1,500 & 1,490 & 1,009 & 1,318 \\
\hline SME 19 (UK) & 1,5 & 4 & 2,000 & 2,333 & 4,000 & 3,000 & 2,500 & 2,500 & 1,478 & 4,016 & 1,904 \\
\hline SME 20 (UK) & 4 & 2 & 2,000 & 2,667 & 2,000 & 2,667 & 2,500 & 2,500 & 4,002 & 1,988 & 2,000 \\
\hline SME 21(UK) & 0,5 & 1 & 1,000 & 1,333 & 2,667 & 1,333 & 1,000 & 1,500 & 0,499 & 1,003 & 0,937 \\
\hline SME 22 (UK) & 1 & 2 & 1,667 & 2,000 & 3,000 & 2,333 & 1,500 & 1,500 & 0,999 & 2,003 & 1,635 \\
\hline SME 23 (UK) & 0,5 & 3 & 1,000 & 1,000 & 2,000 & 1,667 & 1,500 & 1,000 & 0,502 & 3,016 & 0,982 \\
\hline SME 24 (UK) & 1 & 2 & 1,000 & 1,333 & 1,000 & 2,000 & 1,500 & 1,500 & 1,007 & 2,002 & 1,013 \\
\hline SME 25 (UK) & 2 & 1 & 2,000 & 2,333 & 2,333 & 2,333 & 1,500 & 1,500 & 2,010 & 0,989 & 2,020 \\
\hline SME 26 (UK) & 0,5 & 2 & 1,333 & 1,000 & 1,000 & 1,000 & 1,000 & 1,500 & 0,512 & 1,999 & 1,352 \\
\hline SME 27 (UK) & 4,5 & 5 & 3,000 & 3,333 & 3,000 & 3,333 & 3,000 & 3,000 & 4,495 & 4,994 & 2,994 \\
\hline SME 28 (UK) & 1,5 & 2 & 2,000 & 1,667 & 2,333 & 2,667 & 2,000 & 2,500 & 1,481 & 2,010 & 1,966 \\
\hline SME 29 (UK) & 2 & 3 & 3,000 & 2,333 & 3,000 & 2,333 & 1,500 & 2,000 & 1,998 & 2,998 & 3,018 \\
\hline SME 30 (UK) & 0,5 & 1 & 2,667 & 2,000 & 1,667 & 1,667 & 2,000 & 2,000 & 0,519 & 0,988 & 2,721 \\
\hline SME 1 (FR) & 4,5 & 4 & 3,667 & 4,000 & 4,167 & 3,000 & 1,700 & 3,000 & 4,503 & 3,977 & 3,653 \\
\hline SME 2 (FR) & 0,5 & 1 & 2,000 & 1,833 & 4,500 & 2,667 & 1,400 & 2,000 & 0,471 & 1,016 & 1,895 \\
\hline SME 3 (FR) & 0,5 & 1 & 2,000 & 1,833 & 3,167 & 2,667 & 1,900 & 2,000 & 0,487 & 1,009 & 1,954 \\
\hline SME 4 (FR) & 3 & 5 & 2,000 & 1,333 & 4,000 & 2,667 & 1,200 & 2,500 & 2,945 & 5,000 & 1,886 \\
\hline SME 5 (FR) & 1 & 2 & 3,000 & 2,167 & 4,333 & 2,667 & 1,800 & 2,000 & 0,981 & 2,012 & 2,955 \\
\hline SME 6 (FR) & 0,5 & 2 & 2,000 & 1,167 & 3,000 & 2,667 & 1,300 & 1,000 & 0,482 & 2,024 & 1,991 \\
\hline SME 7 (FR) & 3 & 5 & 4,333 & 3,833 & 5,000 & 3,000 & 3,300 & 3,500 & 2,996 & 5,000 & 4,286 \\
\hline SME 8 (FR) & 0,5 & 1 & 1,333 & 1,167 & 1,000 & 2,000 & 1,000 & 1,000 & 0,510 & 1,002 & 1,381 \\
\hline SME 9 (FR) & 0,5 & 1 & 2,333 & 2,000 & 3,167 & 2,667 & 2,500 & 2,000 & 0,493 & 1,007 & 2,305 \\
\hline
\end{tabular}


SME 10 (FR)

SME 11 (FR)

SME 12 (FR)

SME 13 (FR)

SME 14 (FR)

SME 15 (FR)

SME 16 (FR)

SME 17 (FR)

SME 18 (FR)

SME 19 (FR)

SME 20 (FR)

SME 21(FR)

SME 22 (FR)

SME 23 (FR)

SME 24 (FR)

SME 25 (FR)

SME 26 (FR)

SME 27 (FR)

SME 28 (FR)

SME 29 (FR)

SME 30 (FR)

SME 31 (FR)

SME 32 (FR)

SME 33 (FR)

SME 34 (FR)

SME 35 (FR)

SME 36 (FR)

SME 37 (FR)

SME 38 (FR)

SME 39 (FR)

SME 40 (FR)

SME 41 (FR)

SME 42 (FR)

SME 43 (FR)

SME 44 (FR)

SME 45 (FR)

SME 46 (FR)

SME 47 (FR)

SME 48 (FR)

SME 49 (FR)

SME 50 (FR)

SME 51 (FR)

SME 52 (FR)

SME 53 (FR)

SME 54 (FR)

\begin{tabular}{|c|c|c|c|c|c|c|c|c|c|c|}
\hline 0,5 & 1 & 2,667 & 1,833 & 2,167 & 2,667 & 1,800 & 2,000 & 0,496 & 1,003 & 2,698 \\
\hline 3 & 1 & 2,667 & 1,833 & 4,167 & 2,667 & 1,600 & 2,000 & 2,964 & 1,015 & 2,608 \\
\hline 0,5 & 1 & 2,667 & 2,167 & 2,667 & 2,667 & 1,800 & 2,000 & 0,500 & 0,999 & 2,681 \\
\hline 1 & 2 & 3,333 & 3,000 & 2,000 & 2,000 & 3,000 & 3,000 & 1,029 & 1,976 & 3,380 \\
\hline 2,5 & 5 & 4,000 & 4,000 & 2,167 & 2,667 & 3,200 & 4,000 & 2,532 & 4,970 & 4,050 \\
\hline 2,5 & 5 & 3,667 & 4,000 & 3,667 & 2,667 & 3,200 & 4,000 & 2,517 & 4,979 & 3,632 \\
\hline 0,5 & 1 & 3,000 & 3,333 & 4,833 & 2,000 & 3,000 & 3,000 & 0,511 & 0,983 & 2,907 \\
\hline 0,5 & 2 & 3,000 & 3,333 & 2,833 & 2,667 & 3,000 & 3,000 & 0,523 & 1,979 & 3,000 \\
\hline 4 & 1 & 3,333 & 3,167 & 3,500 & 2,667 & 3,000 & 3,000 & 3,997 & 0,985 & 3,316 \\
\hline 0,5 & 1 & 2,000 & 1,833 & 2,167 & 2,667 & 1,400 & 1,500 & 0,501 & 1,002 & 2,020 \\
\hline 4 & 2 & 3,333 & 3,667 & 4,500 & 2,667 & 3,000 & 3,000 & 4,000 & 1,981 & 3,277 \\
\hline 0,5 & 1 & 3,000 & 2,833 & 3,833 & 2,667 & 1,800 & 2,500 & 0,500 & 0,991 & 2,969 \\
\hline 1 & 2 & 3,333 & 3,167 & 3,667 & 2,667 & 1,700 & 2,000 & 1,014 & 1,984 & 3,350 \\
\hline 0,5 & 3 & 3,667 & 3,167 & 4,333 & 3,000 & 2,000 & 2,000 & 0,506 & 2,994 & 3,669 \\
\hline 0,5 & 5 & 3,333 & 2,167 & 4,333 & 2,667 & 1,800 & 2,000 & 0,483 & 5,000 & 3,304 \\
\hline 2,5 & 1 & 2,667 & 3,167 & 2,500 & 2,667 & 2,800 & 3,000 & 2,513 & 0,978 & 2,664 \\
\hline 2 & 4 & 4,333 & 4,500 & 3,167 & 3,000 & 4,000 & 4,000 & 2,036 & 3,965 & 4,359 \\
\hline 0,5 & 1 & 1,333 & 1,167 & 1,000 & 2,000 & 1,000 & 1,000 & 0,510 & 1,002 & 1,381 \\
\hline 1,5 & 2 & 3,333 & 3,500 & 4,667 & 2,667 & 3,000 & 3,000 & 1,504 & 1,986 & 3,267 \\
\hline 0,5 & 1 & 2,667 & 2,833 & 1,000 & 2,667 & 1,600 & 2,000 & 0,534 & 0,973 & 2,770 \\
\hline 0,5 & 1 & 2,333 & 2,500 & 2,167 & 2,667 & 1,700 & 2,000 & 0,514 & 0,988 & 2,360 \\
\hline 0,5 & 1 & 3,333 & 3,000 & 1,667 & 2,667 & 1,700 & 2,000 & 0,532 & 0,973 & 3,440 \\
\hline 0,5 & 2 & 2,667 & 2,833 & 2,667 & 2,667 & 2,900 & 2,000 & 0,521 & 1,987 & 2,689 \\
\hline 0,5 & 1 & 1,667 & 1,833 & 3,167 & 2,667 & 1,700 & 1,500 & 0,492 & 1,009 & 1,625 \\
\hline 0,5 & 2 & 3,333 & 3,000 & 4,000 & 2,667 & 3,000 & 3,000 & 0,502 & 1,994 & 3,290 \\
\hline 3,5 & 5 & 3,333 & 3,167 & 3,667 & 2,667 & 3,000 & 3,000 & 3,497 & 5,000 & 3,308 \\
\hline 1,5 & 3 & 3,667 & 3,500 & 2,500 & 3,000 & 3,000 & 3,500 & 1,518 & 2,980 & 3,698 \\
\hline 1 & 2 & 3,667 & 3,333 & 3,667 & 3,000 & 3,200 & 3,500 & 1,004 & 1,989 & 3,642 \\
\hline 0,5 & 3 & 2,000 & 2,167 & 3,333 & 2,667 & 2,100 & 1,000 & 0,506 & 3,006 & 1,990 \\
\hline 0,5 & 1 & 1,333 & 1,167 & 4,333 & 2,667 & 1,200 & 1,000 & 0,468 & 1,030 & 1,233 \\
\hline 1 & 1 & 2,000 & 2,167 & 4,167 & 3,000 & 2,300 & 1,000 & 0,992 & 1,010 & 1,951 \\
\hline 3,5 & 5 & 3,333 & 3,167 & 2,833 & 2,667 & 3,000 & 3,000 & 3,506 & 4,991 & 3,347 \\
\hline 0,5 & 1 & 1,333 & 1,167 & 1,333 & 2,333 & 1,200 & 1,000 & 0,503 & 1,008 & 1,367 \\
\hline 3 & 3 & 3,333 & 3,500 & 3,167 & 2,667 & 2,900 & 3,000 & 3,013 & 2,980 & 3,337 \\
\hline 0,5 & 1 & 3,333 & 2,833 & 3,500 & 3,000 & 3,000 & 3,500 & 0,493 & 0,996 & 3,291 \\
\hline 0,5 & 1 & 2,667 & 2,167 & 5,167 & 3,000 & 2,900 & 4,000 & 0,451 & 1,018 & 2,486 \\
\hline 1 & 3 & 4,000 & 4,000 & 4,333 & 3,000 & 3,900 & 4,000 & 1,013 & 2,982 & 3,949 \\
\hline 5 & 1 & 2,667 & 2,500 & 3,833 & 3,000 & 1,500 & 1,000 & 4,983 & 0,998 & 2,673 \\
\hline 5 & 2 & 2,333 & 2,167 & 5,000 & 2,667 & 1,600 & 1,000 & 4,967 & 2,014 & 2,264 \\
\hline 0,5 & 1 & 3,000 & 2,333 & 3,333 & 2,667 & 3,000 & 2,500 & 0,496 & 1,002 & 2,981 \\
\hline 0,5 & 3 & 3,333 & 3,167 & 4,000 & 2,667 & 2,700 & 2,500 & 0,510 & 2,991 & 3,313 \\
\hline 1 & 3 & 2,000 & 1,833 & 2,500 & 2,667 & 1,400 & 1,500 & 0,995 & 3,009 & 2,005 \\
\hline 0,5 & 1 & 2,000 & 2,333 & 3,667 & 3,000 & 2,300 & 1,000 & 0,504 & 1,003 & 1,976 \\
\hline 0,5 & 1 & 2,667 & 2,833 & 2,500 & 2,667 & 1,800 & 3,000 & 0,509 & 0,983 & 2,659 \\
\hline 1,5 & 1 & 3,000 & 3,333 & 3,333 & 2,667 & 2,900 & 3,000 & 1,513 & 0,980 & 2,977 \\
\hline \multicolumn{8}{|c|}{ MAPE (\%) } & 1,476 & 0,686 & 1,676 \\
\hline
\end{tabular}

Table 3. UK \& French companies results

\begin{tabular}{l|r|r|r|r|r||r|r|r||r}
\cline { 2 - 9 } & Inp1 & Inp2 & Inp3 & Inp4 & Inp5 & Outp1.Opt & Outp2.Opt & Outp3.Opt & Opt.Sol \\
\hline $\mathbf{( 0 , 2 ; 0 , 3 ; 0 , 5 )}$ & 3,54 & 1 & 2,59 & 1 & 4 & 2,711 & 1,697 & 3,497 & 2,7998 \\
\hline $\mathbf{0 , 2 5} ; \mathbf{0 , 6} ; \mathbf{0 , 1 5})$ & 4,5 & 1 & 2 & 1 & 4 & 1,835 & 2,615 & 1,745 & 2,2895 \\
\hline $\mathbf{( 0 , 3 ; 0 , 2 5 ; 0 , 4 5 )}$ & 4,5 & 1 & 2,93 & 1 & 4 & 1,644 & 1,583 & 1,694 & 1,65125 \\
\hline $\mathbf{( 0 , 4 ; 0 , 5 ; 0 , 1 )}$ & 4,5 & 5,167 & 2,985 & 3,501 & 2,84 & 2,607 & 2,322 & 2,855 & 2,4893 \\
\hline $\mathbf{( 0 , 4 5 ; 0 0 , 2 ; 0 , 3 5 )}$ & 4,5 & 4,708 & 2,78 & 1,33 & 3 & 3,682 & 3,041 & 2,102 & 3,0008 \\
\hline $\mathbf{( 0 , 8 ; 0 , 1 ; 0 , 1 )}$ & 1,167 & 5,167 & 2 & 4 & 4 & 2,223 & 2,316 & 3,123 & 2,3223 \\
\hline $\mathbf{( 0 , 1} ; \mathbf{0}, \mathbf{8} ; \mathbf{0 , 1}$ & 4,5 & 1 & 3 & 4 & 1 & 2,918 & 3,178 & 3,131 & 3,1473 \\
\hline $\mathbf{( 0 , 1 ; 0 , 1 ; 0 , 8 )}$ & 1,167 & 5,167 & 2,996 & 1 & 3,195 & 1,115 & 3,483 & 3,783 & 3,4862 \\
\hline
\end{tabular}

Table 4, Optimal solutions for different weights $\omega_{k}(M=5)$ - French companies

Outp1,Opt: Turnover Optimal value, Outp2,Opt: Business growth Optimal value Outp3,Opt: Environmental management Optimal value, Opt,Sol: Optimal solution. We will use these abbreviations in the two next tables 


\begin{tabular}{|c|c|c|c|c|c|c|c|c|c|}
\hline & Inp1 & Inp2 & Inp3 & Inp4 & Inp5 & Outp1,Opt & Outp2,Opt & Outp3,Opt & Opt,Sol \\
\hline$(0,2 ; 0,3 ; 0,5)$ & 1 & 4 & 1 & 1,801 & 3,031 & 2,023 & 2,553 & 1,702 & 2,0215 \\
\hline$(0,25 ; 0,6 ; 0,15)$ & 1 & 4 & 1 & 3 & 1 & 3,863 & 1,141 & 1,654 & 1,89845 \\
\hline$(0,3 ; 0,25 ; 0,45)$ & 3,333 & 1 & 4 & 2,95 & 1 & 3,949 & 2,453 & 2,008 & 2,70155 \\
\hline$(0,4 ; 0,5 ; 0,1)$ & 3,333 & 2,828 & 1 & 1 & 4 & 3,173 & 3,023 & 3,404 & 3,1211 \\
\hline$(0,45 ; 0,2 ; 0,35)$ & 1 & 4 & 4 & 1,029 & 1 & 2,342 & 1,89 & 1,537 & 1,96985 \\
\hline$(0,8 ; 0,1 ; 0,1)$ & 1 & 4 & 2,157 & 1 & 4 & 2,011 & 2,034 & 4,189 & 2,34575 \\
\hline$(0,1 ; 0,8 ; 0,1)$ & 3,333 & 1 & 1 & 3 & 1 & 4,742 & 4,056 & 4,136 & 4,6128 \\
\hline$(0,1 ; 0,1 ; 0,8)$ & 1 & 3,972 & 1 & 3 & 4 & 2,83 & 1,694 & 2,574 & 1,8956 \\
\hline
\end{tabular}

Table 5, Optimal solutions for different weights $\omega_{k}(M=5)-$ UK companies

\begin{tabular}{l|r|r|r|r|r||r|r|r||r}
\cline { 2 - 9 } & Inp1 & Inp2 & Inp3 & Inp4 & Inp5 & Outp1,Opt & Outp2,Opt & Outp3,Opt & Opt,Sol \\
\hline $\mathbf{( 0 , 2 ; 0 , 3 ; 0 , 5 )}$ & 4,5 & 1 & 4 & 1 & 4 & 3,811 & 2,496 & 1,186 & 2,104 \\
\hline $\mathbf{( 0 , 2 5 ; 0 , 6 ; 0 , 1 5 )}$ & 1 & 5,167 & 1 & 4 & 1 & 1,525 & 1,86 & 2,224 & 1,830 \\
\hline $\mathbf{( 0 , 3 ; 0 , 2 5 ; 0 , 4 5 )}$ & 1 & 3,683 & 4 & 1 & 1 & 4,282 & 1,425 & 1,836 & 2,467 \\
\hline $\mathbf{( 0 , 4 ; 0 , 5 ; 0 , 1 )}$ & 1 & 5,167 & 4 & 1 & 3,565 & 3,832 & 3,136 & 1,852 & 3,286 \\
\hline $\mathbf{( 0 , 4 5 ; 0 , 2 ; 0 , 3 5 )}$ & 4,5 & 5,167 & 1 & 1 & 4 & 3,278 & 3,062 & 2,419 & 2,93 \\
\hline $\mathbf{( 0 , 8 ; 0 , 1 ; 0 , 1 )}$ & 1 & 5,0827 & 1 & 4 & 4 & 2,867 & 2,746 & 1,798 & 2,748 \\
\hline $\mathbf{( 0 , 1 ; 0 , 8 ; 0 , 1 )}$ & 1 & 1 & 2,008 & 4 & 4 & 2,029 & 1,811 & 1,858 & 1,8375 \\
\hline $\mathbf{( 0 , 1} ; \mathbf{0 , 1} ; \mathbf{0 , 8}$ & 3,609 & 1 & 1 & 2,861 & 4 & 2,745 & 3,259 & 2,774 & 2,8196 \\
\hline
\end{tabular}

Table 6, Optimal solutions for different weights $\omega_{k}(M=5)-\mathrm{UK} \&$ French companies

\begin{tabular}{|c|c|c|c|c|c|c|c|c|}
\hline Criteria & Inp1 & Inp2 & Inp3 & Inp4 & Inp5 & Outp1 & Outp2 & Outp3 \\
\hline $\begin{array}{l}\text { Observed } \\
\text { data of } \\
\text { specific SME }\end{array}$ & 3,167 & 3,667 & 2,667 & 3,000 & 3,000 & 3,5 & 5 & 3,333 \\
\hline $\begin{array}{l}\text { Optimum } \\
\text { results }\end{array}$ & 3,54 & 1 & 2,59 & 1 & 4 & 2,711 & 1,697 & 3,497 \\
\hline $\begin{array}{l}\text { Improvemen } \\
\text { t measures }\end{array}$ & $\begin{array}{l}\text { Slightly } \\
\text { improvement } \\
\text { in } \\
\text { environmenta } \\
1 \text { practices }\end{array}$ & $\begin{array}{l}\text { Substantial } \\
\text { reduction of } \\
\text { resources } \\
\text { from } \\
\text { demand } \\
\text { managemen } \\
t\end{array}$ & $\begin{array}{l}\text { Keeping } \\
\text { supply } \\
\text { managemen } \\
\mathrm{t} \text { as is }\end{array}$ & $\begin{array}{l}\text { Substantia } \\
1 \text { reduction } \\
\text { of } \\
\text { attention } \\
\text { on internal } \\
\text { processes }\end{array}$ & $\begin{array}{l}\text { Improvemen } \\
\mathrm{t} \text { in social } \\
\text { management } \\
\text { activities }\end{array}$ & $\begin{array}{l}\text { Turnove } \\
\text { r will go } \\
\text { down }\end{array}$ & $\begin{array}{l}\text { Busines } \\
\text { s growth } \\
\text { is likely } \\
\text { to } \\
\text { reduce }\end{array}$ & $\begin{array}{l}\text { The } \\
\text { concerned } \\
\text { SME is likely } \\
\text { to reflect } \\
\text { enhancement } \\
\text { in } \\
\text { environmenta } \\
1 \text { performance }\end{array}$ \\
\hline
\end{tabular}

Table 7a: Deriving means for improvement (FR)

\begin{tabular}{|c|c|c|c|c|c|c|c|c|}
\hline Criteria & Inp1 & Inp2 & Inp3 & Inp4 & Inp5 & Outp1 & Outp2 & Outp3 \\
\hline $\begin{array}{l}\text { Observed } \\
\text { data of } \\
\text { specific SME }\end{array}$ & 3,167 & 3,667 & 2,667 & 3,000 & 3,000 & 3,5 & 5 & 3,333 \\
\hline $\begin{array}{l}\text { Optimum } \\
\text { results }\end{array}$ & 1.167 & 5.167 & 2.996 & 1 & 3.195 & 1.115 & 3.483 & 3,783 \\
\hline $\begin{array}{l}\text { Improvemen } \\
\text { t measures }\end{array}$ & $\begin{array}{l}\text { Reduction of } \\
\text { environmenta } \\
1 \text { practices }\end{array}$ & $\begin{array}{l}\text { Substantial } \\
\text { improvemen } \\
\mathrm{t} \text { of } \\
\text { resources } \\
\text { from } \\
\text { demand } \\
\text { management }\end{array}$ & $\begin{array}{l}\text { Slightly } \\
\text { improving } \\
\text { supply } \\
\text { managemen } \\
\text { t }\end{array}$ & $\begin{array}{l}\text { Less } \\
\text { attention } \\
\text { to } \\
\text { internal } \\
\text { processe } \\
\mathrm{s}\end{array}$ & $\begin{array}{l}\text { slight } \\
\text { improvemen } \\
\mathrm{t} \text { in social } \\
\text { management } \\
\text { activities }\end{array}$ & $\begin{array}{l}\text { Turnover } \\
\text { will go } \\
\text { down } \\
\text { substantiall } \\
\text { y }\end{array}$ & $\begin{array}{l}\text { Busines } \\
\mathrm{s} \\
\text { growth } \\
\text { is likely } \\
\text { to } \\
\text { reduce }\end{array}$ & $\begin{array}{l}\text { The } \\
\text { concerned } \\
\text { SME is likely } \\
\text { to reflect } \\
\text { enhancement } \\
\text { in } \\
\text { environmenta } \\
\text { l performance }\end{array}$ \\
\hline
\end{tabular}

Table 7b: Deriving means for improvement (FR) for achieving optimal sustainability 


\begin{tabular}{|c|c|c|c|c|c|c|c|c|}
\hline Criteria & Inp1 & Inp2 & Inp3 & Inp4 & Inp5 & Outp1 & Outp2 & Outp3 \\
\hline $\begin{array}{l}\text { Observed } \\
\text { data of } \\
\text { specific SME }\end{array}$ & 3,000 & 2,667 & 4,000 & 2,500 & 1,500 & 4 & 3 & 2,000 \\
\hline $\begin{array}{l}\text { Optimum } \\
\text { results }\end{array}$ & 1 & 4 & 1 & 1,801 & 3,031 & 2,023 & 2,553 & 1,702 \\
\hline $\begin{array}{l}\text { Improvemen } \\
\text { t measures }\end{array}$ & $\begin{array}{l}\text { Substantial } \\
\text { reducing in } \\
\text { environmenta } \\
1 \text { practices }\end{array}$ & $\begin{array}{l}\text { Slightly } \\
\text { improvemen } \\
\mathrm{t} \text { in demand } \\
\text { management }\end{array}$ & $\begin{array}{l}\text { Substantial } \\
\text { reducing } \\
\text { resources } \\
\text { from supply } \\
\text { managemen } \\
\mathrm{t}\end{array}$ & $\begin{array}{l}\text { Substantia } \\
1 \text { reducing } \\
\text { in internal } \\
\text { processes }\end{array}$ & $\begin{array}{l}\text { Substantial } \\
\text { improvemen } \\
t \text { in social } \\
\text { management } \\
\text { activities }\end{array}$ & $\begin{array}{l}\text { Turnove } \\
\text { r will go } \\
\text { down }\end{array}$ & $\begin{array}{l}\text { Busines } \\
\mathrm{s} \text { growth } \\
\text { is likely } \\
\text { to } \\
\text { reduce }\end{array}$ & $\begin{array}{l}\text { The } \\
\text { concerned } \\
\text { SME is likely } \\
\text { to reflect } \\
\text { enhancement } \\
\text { in } \\
\text { environmenta } \\
\text { l performance }\end{array}$ \\
\hline
\end{tabular}

Table 8a: Deriving means for improvement (UK)

\begin{tabular}{l|r|r|r|r|r|r|r|r}
\hline Criteria & Inp1 & Inp2 & Inp3 & Inp4 & Inp5 & Outp1 & Outp2 & Outp3 \\
\hline $\begin{array}{l}\text { Observed } \\
\text { data of } \\
\text { specific SME }\end{array}$ & 3,000 & 2,667 & 4,000 & 2,500 & 2,500 & 2,000 \\
\hline $\begin{array}{l}\text { Optimum } \\
\text { results }\end{array}$ & 3.333 & 1 & 1 & 3 & 4.742 & 4.056 & 4.136 \\
\hline $\begin{array}{l}\text { Improvement } \\
\text { measures }\end{array}$ & $\begin{array}{l}\text { Improving } \\
\text { environmental } \\
\text { practices }\end{array}$ & $\begin{array}{l}\text { Slightly } \\
\text { reducing } \\
\text { demand } \\
\text { management }\end{array}$ & $\begin{array}{l}\text { Substantial } \\
\text { reducing } \\
\text { resources } \\
\text { from supply } \\
\text { management }\end{array}$ & $\begin{array}{l}\text { Improving } \\
\text { internal } \\
\text { processes }\end{array}$ & $\begin{array}{l}\text { Slightly } \\
\text { reducing } \\
\text { social } \\
\text { management } \\
\text { activities }\end{array}$ & $\begin{array}{l}\text { The } \\
\text { is likely } \\
\text { to } \\
\text { enhance } \\
\text { concerned } \\
\text { SME is likely } \\
\text { to reflect } \\
\text { enhancement } \\
\text { in } \\
\text { environmental } \\
\text { performance }\end{array}$ \\
\hline
\end{tabular}

Table 8b: Deriving means for improvement (UK) for optimal sustainability 


\section{APPENDIX A \\ Small and Medium Enterprises (SMEs) Sustainability Structure}

The objective of this study is to derive sustainability performance of SMEs and suggest improvement measures through benchmarking with most appropriate SMEs, Each participating SME will be informed through formal report on their performance and means for improvement,

Personal Information (optional):

Name:

Contact:

Telephone:
Company:

Email:

Please tick at the appropriate place:

1. Brief description of the company:
a) Location(State): East
North
South
West
Central
b) Industry type: Manufacturing R\&D Pharmaceuticals
Process
Service Others(Please specify)
Construction
c) Major products/services:
d) Business Start Year:

e) Turnover (in Rupees): Below 10lakh 10-25lakh

25 - 50lakh

Above 50lakh

f) Growth in last 5 years: $0 \%-10 \%$

$10 \%-30 \%$

$30 \%-50 \%$

Above 50\%

g) Number of employees: 5-10 10-50 $50-100100-250$

Above 250

h) Growth in employee number: $0 \%-10 \%$

$10 \%-30 \%$

$30 \%-50 \%$

Above 50\%

i) Major customers: OEMs International

\section{PSUs}

Retailers

End-customers

National

j) Percentage of international customers: $0 \%-10 \% \quad 10 \%-30 \% \quad 30 \%-50 \%$

Above $50 \%$
k) Major suppliers: Steel Manufactures Chemical Processing Companies

Component Manufacturers Others(Please specify)

Supply chain issues and challenges:

How much would you rate on a scale of 1-5: 5=Very high, 4=High, 3=Medium, 2=Low and $1=$ Not at all

2. Do you face supply uncertainty: $\quad \begin{array}{llllll}5 & 4 & 3 & 2 & 1\end{array}$

3. Do you face demand uncertainty: $\begin{array}{llllll}5 & 4 & 3 & 2 & 1\end{array}$

4. Do you face internal operational uncertainty: $\begin{array}{llllll}5 & 4 & 3 & 2 & 1\end{array}$

5. Do you face cash flow issues : $\quad \begin{array}{llllll}5 & 4 & 3 & 2 & 1\end{array}$

6. Do you feel customers drives your environmental and social practices $\begin{array}{llllll}5 & 4 & 3 & 2 & 1\end{array}$

7. Do you feel Government drives your environmental and social practices $\begin{array}{llllll}5 & 4 & 3 & 2 & 1\end{array}$

8. Do you feel there is a communication issue within the organisation $\quad \begin{array}{llllll}5 & 4 & 3 & 2 & 1\end{array}$

9. Do you feel there is an issue with leadership within the organisation $\begin{array}{llllll}5 & 4 & 3 & 2 & 1\end{array}$

10. Do you feel there is an issue with middle level management within the organisation $\begin{array}{llllll}5 & 4 & 3 & 2 & 1\end{array}$ 
11. Do you feel there is an issue with workmen within the organisation $\begin{array}{llllll}5 & 4 & 3 & 2 & 1\end{array}$

\begin{tabular}{|c|c|c|c|}
\hline Criteria & Practices & \multicolumn{2}{|l|}{ Performances } \\
\hline & $\begin{array}{l}5=100 \%, 4=99-50 \%, 3=49 \%-20 \%, \\
2=\text { Less than } 20 \%, 1=\text { Not adopted at all }\end{array}$ & \multicolumn{2}{|c|}{$\begin{array}{l}5=\text { Very high, } 4=\text { High, } 3=\text { Medium, } 2=\text { Low } \\
\text { and } 1=\text { Not adopted at all }\end{array}$} \\
\hline SRM & $\begin{array}{l}\text { Percentage of suppliers with whom } \\
\text { you have long term relationship? }\end{array}$ & $\begin{array}{l}\text { How effective is supplier } \\
\text { relationship management? }\end{array}$ & \\
\hline CRM & $\begin{array}{l}\text { Percentage of customer with whom } \\
\text { you have long term relationship? }\end{array}$ & $\begin{array}{l}\text { How effective is customer } \\
\text { relationship management? }\end{array}$ & \\
\hline $\begin{array}{l}\text { Capacity } \\
\text { Utilisation }\end{array}$ & $\begin{array}{l}\text { Percentage of capacity utilisation } \\
\text { practices? }\end{array}$ & $\begin{array}{l}\text { How effective is capacity } \\
\text { utilisation? }\end{array}$ & \\
\hline $\begin{array}{l}\text { Forecasting } \\
\text { Demand }\end{array}$ & Percentage of forecasting error? & $\begin{array}{l}\text { How effective is your demand } \\
\text { forecasting? }\end{array}$ & \\
\hline \multicolumn{4}{|c|}{$5=$ Very high, $4=$ High, $3=$ Medium, $2=$ Low and $1=$ Not adopted at all } \\
\hline $\begin{array}{l}\text { Production } \\
\text { Planning }\end{array}$ & $\begin{array}{l}\text { Do you have Production Planning } \\
\text { practices? }\end{array}$ & $\begin{array}{l}\text { How effective is your Production } \\
\text { Planning practices? }\end{array}$ & \\
\hline $\begin{array}{l}\text { Quality } \\
\text { Management } \\
\text { System }\end{array}$ & Have you adopted ISO 9000? & How effective is ISO $9000 ?$ & \\
\hline $\begin{array}{l}\text { Environment } \\
\text { Management } \\
\text { System }\end{array}$ & $\begin{array}{l}\text { Have you adopted ISO } 14000 / \\
\text { Environment } \\
\text { System? }\end{array}$ & 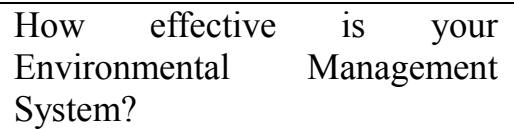 & \\
\hline $\begin{array}{l}\text { Chartered } \\
\text { Quality } \\
\text { Institute }\end{array}$ & Have you adopted CQI? & How effective is CQI? & \\
\hline Lean approach & $\begin{array}{l}\text { Have you adopted formal lean } \\
\text { approach in manufacturing? }\end{array}$ & $\begin{array}{l}\text { How effective is your formal lean } \\
\text { approach in manufacturing? }\end{array}$ & \\
\hline $\begin{array}{l}\text { Raw Material } \\
\text { Inventory }\end{array}$ & $\begin{array}{l}\text { Have you adopted raw material } \\
\text { inventory policy? }\end{array}$ & $\begin{array}{l}\text { How effective is your raw } \\
\text { material inventory policy? }\end{array}$ & \\
\hline $\begin{array}{l}\text { Finished } \\
\text { Product } \\
\text { Inventory } \\
\end{array}$ & $\begin{array}{l}\text { Have you adopted finished product } \\
\text { inventory policy? }\end{array}$ & $\begin{array}{l}\text { How effective is your finished } \\
\text { product inventory policy? }\end{array}$ & \\
\hline $\begin{array}{l}\text { Work in } \\
\text { progress (WIP) }\end{array}$ & Do you have high WIP? & How effective is your WIP? & \\
\hline $\begin{array}{l}\text { Formal Risk } \\
\text { Management }\end{array}$ & $\begin{array}{l}\text { Have you adopted any formal risk } \\
\text { management method in your } \\
\text { production and operations } \\
\text { management? }\end{array}$ & $\begin{array}{l}\text { How effective is your risk } \\
\text { management? }\end{array}$ & \\
\hline $\begin{array}{l}\text { Maintenance } \\
\text { Policy }\end{array}$ & $\begin{array}{l}\text { Have you adopted Maintenance } \\
\text { Policy? }\end{array}$ & $\begin{array}{l}\text { How effective is your } \\
\text { Maintenance Policy? }\end{array}$ & \\
\hline $\begin{array}{l}\text { Waste } \\
\text { Management }\end{array}$ & $\begin{array}{l}\text { Have you adopted any formal } \\
\text { waste management policy? }\end{array}$ & $\begin{array}{l}\text { How effective is your waste } \\
\text { management? }\end{array}$ & \\
\hline $\begin{array}{l}\text { Reverse } \\
\text { logistics policy }\end{array}$ & $\begin{array}{l}\text { Have you adopted reverse logistics } \\
\text { policy? }\end{array}$ & $\begin{array}{l}\text { How effective is your reverse } \\
\text { logistics policy? }\end{array}$ & \\
\hline $\begin{array}{l}\text { Emissions } \\
\text { Control }\end{array}$ & $\begin{array}{l}\text { Do you adopt practices to reduce } \\
\text { emission control? }\end{array}$ & $\begin{array}{l}\text { How effective is your emission } \\
\text { control? }\end{array}$ & \\
\hline $\begin{array}{l}\text { Energy } \\
\text { Efficiency } \\
\text { Program }\end{array}$ & $\begin{array}{l}\text { Have you adopted energy } \\
\text { efficiency program? }\end{array}$ & $\begin{array}{l}\text { How effective is your energy } \\
\text { efficiency program? }\end{array}$ & \\
\hline $\begin{array}{l}\text { Social Health } \\
\text { and } \\
\text { Occupational } \\
\text { Hazard } \\
\end{array}$ & $\begin{array}{l}\text { Have you adopted social health and } \\
\text { occupational hazard practice? }\end{array}$ & $\begin{array}{l}\text { How effective is your social } \\
\text { health and occupational hazard } \\
\text { practice? }\end{array}$ & \\
\hline $\begin{array}{ll}\text { Training } & \text { for } \\
\text { employee } & \end{array}$ & $\begin{array}{l}\text { Do you provide training for } \\
\text { employee? }\end{array}$ & $\begin{array}{l}\text { How effective is training for } \\
\text { employee? }\end{array}$ & \\
\hline $\begin{array}{l}\text { Employee } \\
\text { Welfare }\end{array}$ & $\begin{array}{l}\text { Do you adopt employee welfare } \\
\text { practices? }\end{array}$ & $\begin{array}{l}\text { How effective is employee } \\
\text { welfare practices? }\end{array}$ & \\
\hline
\end{tabular}


